Int. J. Dev. Biol. 56: 551-565 (2012)

doi: $10.1387 / \mathrm{ijdb} .113464 \mathrm{pp}$

\title{
Coordinated modulation of cellular signaling through ligand-gated ion channels in Hydra vulgaris (Cnidaria, Hydrozoa)
}

\author{
PAOLA PIEROBON* \\ Istituto di Cibernetica "E. Caianiello" C.N.R., Naples, Italy
}

\begin{abstract}
Cnidarians lack well developed organs, but they have evolved the molecular and cellular components needed to assemble a nervous system. The apparent 'simplicity' of the cnidarian nervous net does not occur at the cellular level, but rather in the organisation of conducting systems. Cnidarian neurons are in fact electrically excitable, show the typical extended morphology and are connected by chemical synapses or gap junctions. They have been regarded as peptidergic, given the wealth of neuropeptides generally distributed along neurites and in cell bodies, supporting the hypothesis of a modulatory role in neurotransmission. However, the presence of clear-cored, as well as dense-cored synaptic vesicles in cnidarian neurons suggests both fast and slow synaptic transmission mechanisms. In fact, biochemical and functional evidence indicates that classical neurotransmitters and their metabolic partners are present in cnidarian tissues, where they are involved in coordinating motility and behavior. We have identified and characterized in Hydra tissues receptors to the inhibitory and excitatory amino acid neurotransmitters, GABA, glycine and NMDA, that are similar to mammalian ionotropic receptors in terms of their biochemical and pharmacological properties. These receptors appear to regulate pacemaker activities and their physiological correlates; in the live animal, they also affect feeding behavior, namely the duration and termination of the response elicited by reduced glutathione, with opposite actions of GABA and glycine or NMDA, respectively. These results suggest that modulation of cellular signaling through ligand-gated-ion channels is an ancient characteristic in the animal kingdom, and that the pharmacological properties of these receptors have been highly conserved during evolution.
\end{abstract}

KEY WORDS: GABA receptor, glycine receptor, glutamate receptor, feeding response

\section{Introduction}

The freshwater polyp Hydra vulgaris (Cnidaria: Hydrozoa) has been a choice experimental model for studies of regeneration, morphogenesis, and development since Trembley's pioneer experiments in 1744 (Tardent, 1963; Gierer, 1977; Bode and David, 1978; Bode et al., 1986). Modern research focuses on the gene families regulating axial patterning, stem cell biology and neurogenesis (Galliot and Schmid, 2002; Holstein et al., 2003; Galliot et al., 2009, 2011); the recent publication of the genomes of Nematostella vectensis (Putnam et al., 2007) and Hydra magnipapillata (Chapman et al., 2010) now adds a basic framework for a comparative approach to the evolution of regulated developmental genetic programs.

Since its discovery, Hydra has also proven a fashionable model organism for studies of nervous form and function, as a representative of the earliest phylum in which a nervous system evolved. The

*Address correspondence to: Paola Pierobon. Istituto di Cibernetica E Caianiello C.N.R., Via Campi Flegrei 34, 80078 Pozzuoli (Naples), Italy.
e-mail: p.pierobon@cib.na.cnr.it

Final, author-corrected PDF published online: 31 May 2012

ISSN: Online 1696-3547, Print 0214-6282

(c) 2012 UBC Press

Printed in Spain 
simple polyp anatomy allows the view that questions concerning development and functions of conducting systems, movement co-ordination and handling of sensory information can be studied as well as, and perhaps more easily than, in more complex organisms. Furthermore, Hydra has been regarded as an ideal model system in which the paradox of co-existing cellular plasticity and defined neural functions could be resolved. In his plenary lecture at the NATO Workshop on "Evolution of the first nervous systems" G. O. Mackie (1989a) could state '...Speculations about evolution have an irresistible fascination, partly because they are hard to prove wrong, partly because they make us think about origins and look for clues in development. Cnidarians may have been the first metazoans to evolve.... Given however, that of the surviving phyla they alone retain the presumably ancestral (diplobastic) body plan, it becomes especially interesting to look at their nervous systems for clues as how nerves evolved.... Molecular biology may (probably will) eventually help us reconstruct phylogeny, and place the cnidarians in their proper place on the many-branched tree of neural evolution, but we are still far from this point...'

Mackie's foresight is proving well founded. Other papers in this issue deal with advances in our present understanding of neuronal development in Hydraand its contribution to studies on the origin of neurogenesis. This review focuses on a specific topic concerning the molecular machinery of chemical neurotransmission, namely the occurrence and properties of neurotransmitter receptors in Hydra, updating current knowledge and exploring future directions for studies of cnidarian neurophysiology. A brief description of $\mathrm{Hy}$ $d r a$ and cnidarian neurophysiology is also presented in a historical perspective; students of the field will find this part rather sketchy, a choice made for the purpose of not abusing beyond measure the readers' patience. The last part of the review summarizes data on the biological roles of amino acid receptors, in particular in the modulation of a complex behavior, the feeding response.

\section{The 'elementary' nervous system}

The simple body plan of cnidarians is made of columnar epithelia supported by basement membranes, arranged in a sac with radial symmetry; in jellyfish, the sack culminates in an oral structure (the manubrium), surrounded by tentacles; in the case of polyps or anemones, the manubrium and tentacles (often called a head) form the apical part of a column which often rests upon a disc (the 'foot') (see in this issue Martinez and Bridge, 2012). Cnidarians lack well developed organs, but they have evolved the molecular and cellular components needed to assemble a nervous system. Polyps, medusae and sea anemones show major differences in neural anatomy and physiology, thus discouraging generalizations about primitive nervous systems. However, a common characteristic is the organization of cells in distributed nerve nets.

Cnidarian nerve nets have been the obvious candidate for comparative and evolutionary studies on the origin of synaptic transmission. Parker's theory (1919) that 'the elementary nervous system' originated in three successive phylogenetic stages, as a means to co-ordinate independent effector cells in response to environmental changes, has prompted innumerable studies and speculations on the origin, structure and physiology of conducting systems (see reviews by Pantin, 1952; Passano, 1963; Josephson, 1974; Shelton, 1982; Satterlie and Spencer, 1987). The lack of a recognizable brain encouraged the speculation that in these animals spreading of excitation was attained by way of diffuse, non-polarized conducting systems such as nerve nets. The organization into a net could well represent an adaptive response to ensure distribution and co-ordination of electrical activity in large portions of tissues, or perhaps to the radial symmetry of the body plan (Bullock and Horridge, 1965). The discovery of epithelial conduction in hydromedusae (Mackie and Passano, 1968; Spencer, 1974; Anderson, 1980), but not in anthozoans, was construed as further evidence for the primitive character of conducting systems in these organisms.

In the middle of last century, the explosion of electrophysiological studies both on vertebrate and invertebrate nerves and neurons, primed by the discovery of the action potential by Hodgkin and Huxley (1939), was rewarded by two Nobel prizes assigned in 1963 to Eccles, Hodgkin and Huxley for the theory of electrical signalling in excitable structures (Eccles, 1957), and in 1970 to Katz, von Euler and Axelrod for the discovery of quantal neurotransmitter release at the synapses (Katz, 1971). These new facts and theories renewed the interest for the functional properties of cnidarian neurons and nerves. In the following decades new techniques, electron microscopy, immunocytochemistry, intracellular and voltage clamp electrophysiology, have drawn an updated picture of cnidarian neurophysiology, based on findings from anatomical, ultrastructural, biochemical and functional studies (Anderson, 1985; Spencer, 1989; Satterlie, 2002; Mackie, 1989a, 1990). There is now ample evidence that the 'simplicity' of the cnidarian nervous net does not occur at the cellular level but rather in the organisation of conducting systems (Kass-Simon and Pierobon, 2007). Cnidarian neurons, in fact, are electrically excitable, show the typical extended morphology and are connected by chemical synapses, gap junctions or syncytial bridges (Jha and Mackie, 1967; Filshie and Flower, 1977; Wood, 1979; Westfall, 1987, 1996; Holtman and Thurm, 2001). They produce $\mathrm{Na}^{+}$-dependent action potentials, interact by chemical or electrical synapses with other neurons or with nematocytes, muscle processes and other effector cells, generate rhythmic electrical activity and coordinate responses to sensory stimulation, integrating information from a variety of conduction pathways (Anderson, 2004). While modern technical advancements have reduced the need for easy-to-handle experimental models, a full understanding of cnidarian neurophysiology could still contribute useful information on conserved properties and functions of nervous systems.

\section{The nervous net of Hydra: anatomy, ultrastructure and physiology}

The first description of a medusan nervous system by the Swiss paleontologist and geologist Louis Agassiz in 1850 met considerable skepticism, because of the lack of a central brain (Mackie, 1989b). By the end of the century and in the following decades, however, several studies confirmed the occurrence of a nervous net lacking a recognizable center in many cnidarian species (Horridge and MacKay, 1965; Lentz, 1966). Still, in the 1961 Coral Gables workshop dedicated to cnidarian biology, doubts were openly voiced about the predicted neuronal nature of the cells identified in Hydra by classical histological methods such as silver impregnation or vital staining by methylene blue, but not yet confirmed by electron microscopy preparations (see floor discussion in Lenhoff and Loomis, 1961). The seminal work by Jane Westfall and coworkers, who described in detail the ultrastructure of nerve cells and synapses in Hydra sp. and other coelenterates contributed 


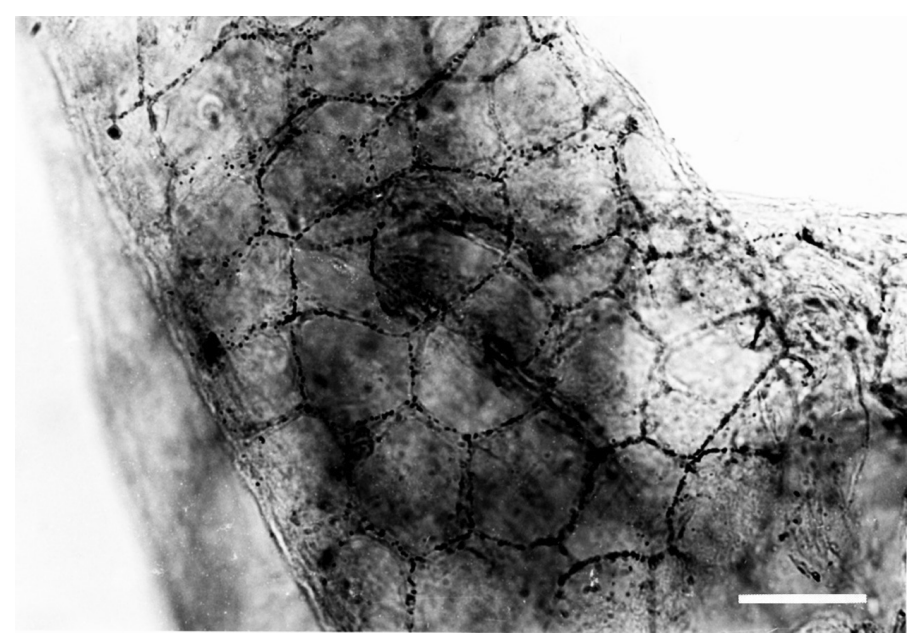

Fig. 1. The nervous net at the hypostome - tentacle junction of Hydra oligactis. Whole mount silver nitrate staining. Scale bar: $50 \mu \mathrm{M}$.

to definitely establish the presence of synaptic connections in the following years, erasing residual doubts on the existence of a nervous system (Westfall, 1970, 1973a, 1973b, 1988, 1996, 2002; see also Kass-Simon and Pierobon, 2007 for review).

Among Cnidaria, Hydrapossesses perhaps one of the anatomically simplest nervous systems: neurons are connected to one another forming a nerve net that extends throughout the body as shown here (Fig. 1), with a concentration of neurons in the regions of the head and the foot. The nerve net is composed of two morphologically distinguishable cell types, sensory cells and interneuronal or ganglion cells. Sensory cells are inserted between epithelial cells perpendicular to the mesoglea; they have elongated somas that project from myonemes to the surface of the cell layer, with a ciliary cone at the apical end. Ganglion nerve cells lie parallel to muscle processes at the basal end of epithelial cells; they are interconnected by synapses with lucent- and dense-core vesicles (Davis et al., 1968; Kinnamon and Westfall, 1981; Westall and Kinnamon, 1978, 1984). They also impinge on effector cells by way of synaptic foci or neurosecretory endings.

Current knowledge indicates that in Hydra species the nerve net is not diffused homogenously throughout the body, but shows a far greater structural and functional complexity (Koizumi, 2007). An immunocytochemical study performed with anti-RFamide antibodies (Koizumi et al., 1992) demonstrated the occurrence of a nerve ring at the base of the hypostome in Hydra oligactis, formed by neurites of ganglion cells running circumferentially in a bundle, providing the first anatomical evidence of the existence of a ring structure previously inferred by electrophysiological studies (Kass-Simon, 1972). Labeling with different monoclonal antibodies or antibodies raised against different Hydra neuropeptides identified distinct subsets of neurons with specific regional distributions, dependent on axial position (Koizumi and Bode, 1986, 1991; Koizumi et al., 2004). A remarkable feature of the net is, in fact, its plasticity: neurons are continually migrating to be eliminated at the apical and basal ends of the polyp together with the adjacent epithelia (Dunne et al., 1985; Bode et al., 1986), thus implying that extensive synapse remodeling must occur in physiological conditions. Furthermore, though Hydra polyps have no recognizable organs, a detailed ultrastructural analysis of the epithelial cells of the tentacles, the battery cells, showed that these cells enclose in their cytoplasm sensory and ganglion neurons as well as myonemes and different types of nematocytes, anchored by gap and septate junctions respectively (Hufnagel et al., 1985). The authors suggest that these cell complexes may represent the functional units by which tentacles exert their functions: sensory perception, bending and contraction, prey capture (Hufnagel and Kass-Simon, 1988).

Considerable efforts were devoted to the study of Hydra electrophysiology, despite the difficulties encountered in recording from small, dispersed nerve cells. The apparent lack of a centralized ganglion or group of ganglia and the existence of diffuse epithelial conduction via gap junctions (Mackie and Passano, 1968; Anderson, 1980) initially favored the view that in Hydra electrical activity may pass from contractile myoepithelium to unpolarized nerve nets. However, extensive work by many researchers demonstrated that in Hydra through-conducting systems exist that exhibit complex patterns of rhythmic electrical activity, generated by pacemaker loci, challenging Parker's theory of independent effectors. Body contraction and elongation are controlled by ectodermal and endodermal pacemaker systems, respectively, while a third pacemaker system controls tentacle contractions (Passano, 1963; Passano and McCullough, 1964, 1965; Macklin and Josephson, 1971; Rushforth, 1971; Rushforth and Burke, 1971; Rushforth and Hofman, 1972; Josephson, 1974; Kass-Simon, 1972, 1976; Kass-Simon andPassano, 1978). Electron microscopy studies by Lentz (1966, 1968), Westfall and collaborators (1970,1971, 1987, 1996) and others described both electrical and chemical synapses, bearing clear-and dense-cored vesicles, in Hydra neurons. Their importance in the coordination of electrical activity of excitable structures became steadily acknowledged (Anderson and Spencer, 1989); conversely, in one study no electrotonic coupling or dye exchange was detected between epithelial cells of Hydra attenuata (de Laat et al., 1980). At present, chemical synaptic transmission is regarded as the basis for neuronal signaling in Hydra, the question having shifted to what molecules and proteins make the signaling system(s).

\section{The molecular machinery of chemical neurotransmission in eumetazoans}

\section{Two types of signals in chemical neurotransmission: neurotransmitters and neuropeptides}

Chemically mediated synaptic transmission is one of the mechanisms by which intercellular signaling occurs between neurons, or between a neuron and its target cell(s); it relies on two major components: neurotransmitters, stored in presynaptic terminals and released at need in the synaptic cleft, and postsynaptic receptors, membrane proteins that specifically recognize and bind to released transmitters. These receptors convert chemical into electrical signals, thus ensuring transfer of information.

Neurons use many different molecules to convey information; very often, they make both a conventional neurotransmitter (such as glutamate, GABA or dopamine) and one or more neuropeptides. Neurotransmitters are generally packaged in small, clear synaptic vesicles, clustered in presynaptic terminals, and peptides in large dense-cored vesicles, found in all parts of the neuron (see in this issue Fujisawa and Hayakawa, 2012). Rather ironically, some of these substances were first discovered and identified as signaling molecules in lower vertebrates (acetylcholine, Loewi, 1921) or in invertebrates (GABA, Otsuka, 1966); but proof of their status as neurotransmitters and the present extensive knowledge about their 
biochemistry, pharmacology and physiology derives from studies on mammalian central nervous systems (CNS).

More recently, new molecules such as nitric oxide (NO), carbon monoxide, and D-serine have been proposed as neurotransmitters; differently from conventional transmitters, they are not stored in synaptic vesicles, are not released by exocytosis, and do not act at postsynaptic membrane receptors. D-serine is synthesized and stored in astrocytes rather than neurons (Bohening and Snyder, 2003). The discovery of atypical neurotransmitters opens new exciting perspectives for studies of cellular signalling. It is interesting to note that at least two of these molecules, NO and D-serine, are involved in modulation of biological activities in cnidarians (see Kass-Simon and Pierobon, 2007, for review).

\section{Two types of receptors are involved in chemical neurotransmission}

Chemical synapses can produce fast, short-term transmission carried by small molecules, the "classical" transmitters such as acetylcholine, amino acids, biogenic amines; or slow, prolonged action often due to secretion of small neuroactive peptides. Neurotransmitters modify the activity of one or a few adjacent cells by binding to a specific membrane receptor; the nature of the receptor, i.e. ionotropic (forming ion-channel pores) or metabotropic (most often G protein-coupled receptors, GPCRs), determines the

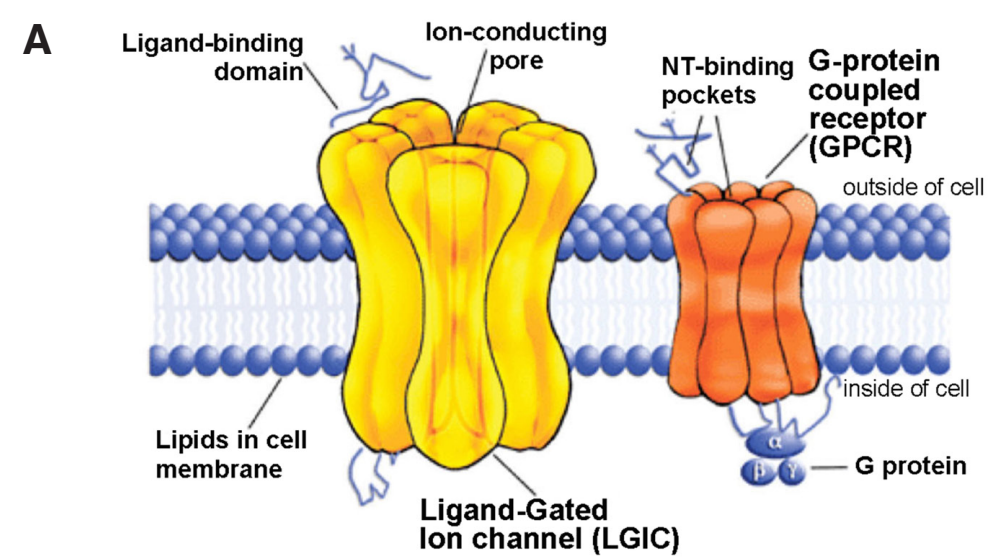

B

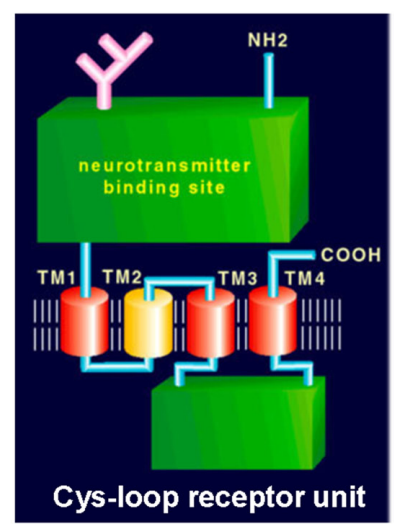

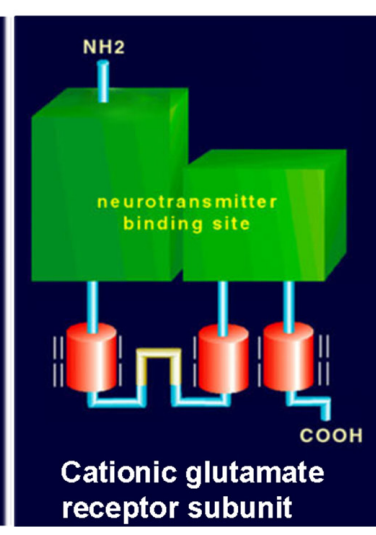

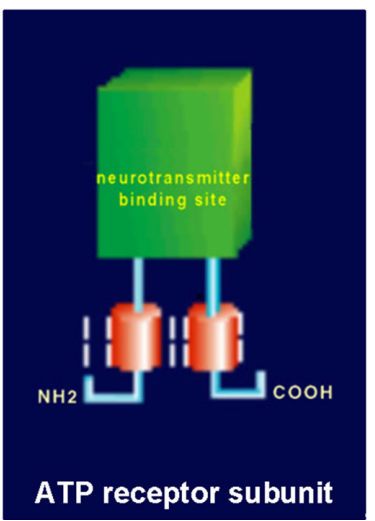

Fig. 2. Structure of the two classes of receptors involved in chemical neurotransmission. (A) Schematic drawing of a ligand-gated ion channel receptor ( $L G I C$, left) and a G protein-coupled receptor (GPCR, right). (B) Transmembrane subunit arrangement in the three different LGIC classes (schemes reprinted from the Ligand-Gated lon Channel database EMBL EBI: wWW. niaaa.nih.gov). mode of action of the transmitter. The former can produce brief conductance changes of the postsynaptic membrane whereas the latter induce the production of intracellular second messengers, usually intermediate G-proteins. Both types of receptors exist for the majority of classical transmitters, while neuropeptides use almost exclusively metabotropic receptors. GPCRs are heteromeric protein complexes formed by seven transmembrane domains, activating cellular responses through two main signal transduction pathways: the cAMP signal pathway and the phosphatidylinositol signal pathway (Fig. 2A). The ligands for this large protein family include opsins, odorants, pheromones, hormones, growth factors, besides neurotransmitters; part of these are orphan receptors, i.e, no specific ligand has yet been identified. The size of the GPCR superfamily is unknown, but about 800 genes have been predicted from human genome sequence analysis (Foord et al., 2005).

\section{Ligand-gated ion channel (LGIC) receptors form three super- families}

In the last thirty years advances in molecular biology and genomics allowed the identification and cloning of the protein components of ligand- and voltage-gated ion channels as well as metabotropic receptors. These studies have discovered a multiplicity of protein subunits, grouped into classes on the basis of amino acid sequence homology; within classes there are further subdivisions into subunit isoforms, some of which exhibit alternative splice variants. This heterogeneity is considered to be responsible for the distinct pharmacological and functional properties displayed by the various subunit configurations. Despite the extraordinary diversity of molecular receptor components, these studies have also revealed a considerable similarity in amino acid sequence and structure, leading to current classification of postsynaptic receptor proteins in different gene families (Alexander et al., 2007).

The prevalent forms of neurotransmitter receptors belong to the superfamily of Ligand-Gated Ion Channel (LGIC) receptors, both excitatory (acetylcholine, glutamate, serotonin) and inhibitory (GABA $_{A}$, glycine, glutamate-gated $\mathrm{Cl}^{-}$channels). LGIC receptors are heteromeric or homomeric transmembrane protein complexes that can exist under different conformations, at least one forming a pore through the membrane connecting the two neighbour compartments (Fig. 2A). The equilibrium between the various conformations is affected by the binding of ligands on the channels. Phenomenologically, the ligands "open" or "close" the channel. The allosteric binding site of endogenous ligands on LGIC protein complexes is normally located on a different portion of the protein than the ion pore. The direct link between ligand binding and ion channel opening or closing is characteristic of these receptors. There are three different gene superfamilies of extracellularly activated LGIC subunits: the Cys-loop superfamily, glutamate-activated cationic channels, and ATPgated channels, or purinergic receptors (Fig. 2B). The Cys-loop superfamily is comprised of 
nicotinic acetylcholine receptors ( $\mathrm{nAChR}$ ), serotonin receptors, $\mathrm{GABA}_{A}$ receptors $\left(\mathrm{GABA}_{A} \mathrm{R}\right)$ and glycine receptors (GlyR). Some glutamate, histamine and serotonin-activated anionic channels also belong to the Cys-loop superfamily. The structure of Cys-loop LGIC receptors has been the object of extensive biochemical and molecular investigation. Current knowledge derives from X-ray crystallography data on the soluble ACh binding protein (Brejc et al., 2001) and subsequently from the water-soluble portion of the nAChR $\alpha 1$ subunit (Dellisanti et al., 2007) that confirmed and resolved previous findings, making the $\mathrm{ACh}$ receptor a paradigm for the topology of LGIC.

Cys-loop receptors are heteromeric or homomeric protein pentamers. Each subunit has a N-terminal extracellular domain containing a signature loop formed by a disulfide bond between two cysteine residues separated by 13 highly conserved amino acids, four transmembrane domains of about 20 amino acids that form the central pore, with a large intracellular loop between M3 and M $4 \alpha$-helices, and a C-terminal extracellular domain, the most divergent part of the sequence; two to five binding sites per receptor are located on the $\mathrm{N}$-terminus domain. In particular, receptors to GABA are assembled from a family of 19 homologous subunit gene products ( $\alpha 1-6, \beta 1-3, \gamma 1-3, \delta, \varepsilon . \theta$; three $\rho$ subunits, related to $\mathrm{GABA}_{\mathrm{C}}$ receptors also are included in the family) and form different, normally heteromeric, pentamers (Barnard et al., 1998;

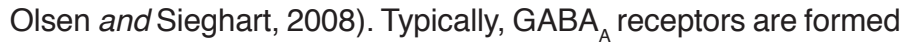
by two copies of $\alpha$, two copies of $\beta$ and one copy of either $\gamma, \delta$ or $\varepsilon$ subunits, out of the hundreds of theoretically possible combinations. Receptor composition and subunit selectivity for drugs is currently the objective of massive research efforts, given the fundamental role of GABARs in brain function.

Receptors to glycine are homomeric or heteromeric pentamers comprised of five subunits, four $\alpha(1-4)$, and one $\beta$ subunit. The $\beta$ subunit is responsible for anchoring GlyRs to the subsynaptic cytoskeleton via the cytoplasmic protein gephyrin (Betz et al., 1999; Lynch, 2004). A distinctive feature of glyRs is the presence of a second cys-loop, 45 residues downstream, that is critical for ligand binding (Rajendra et al., 1995). As GABARs, GlyRs gate a $\mathrm{Cl}^{-}$channel, thus hyperpolarizing membranes of the target cells. However, glycine also acts as a NMDA co-agonist at the glycinebinding site of the NMDA receptor in vertebrate CNS, thus exerting an excitatory action (Kleckner and Dingledine, 1988).

The ionotropic glutamate receptor family (iGluRs) is comprised of at least three receptor subtypes defined by their pharmacological characteristics, namely selective binding to different glutamate agonists, the $\alpha$-amino-3-hydroxy-5-methylisoxazole-4-propionic acid (AMPA) receptors, the kainate receptors, and the N-methyl-Daspartic acid (NMDA) receptors (Dingledine et al., 1999). Receptor topology has been only recently clarified (Mayer and Armstrong, 2004): eukaryotic iGluRs are made of four subunits, each with three transmembrane segments. Each subunit contains an extra-cellular amino-terminal domain followed by half of the agonist-binding core, two transmembrane domains separated by a pore loop ion channel, the second half of the agonist-binding core and a third transmembrane segment. The M2 segment does not cross the membrane but forms an intracellular loop. The C-terminus is located within the cell and has a variable length.

AMPA receptors are assembled from GluR1-GluR4 subunits, and kainate receptors are made of GluR5-GluR7 plus KA1/KA2 subunits of a different gene family. NMDA receptors consist of two
NR1 and two NR2 subunits, each containing three transmembrane domains The glycine binding site is formed by two distinct extracellular regions, S1 and S2, of the NR1 subunit, whereas the homologous domains of the NR2 subunit mediate glutamate binding. NR1 subunits are also required for receptor trafficking and assembly. Receptor activation opens postsynaptic cation channels with different degrees of permeability, thus depolarizing the postsynaptic membrane. NMDA-gated channels are also highly permeable to $\mathrm{Ca}^{2+}$ and to other divalent cations; they are regulated by a voltagedependent $\mathrm{Mg}^{2+}$ block, and their activation requires simultaneous binding of both glutamate and the co-agonist glycine.

\section{Origin and evolution of ligand-gated ion channels}

Phylogenetic studies have shown that LGIC receptors probably derive, as a result of divergent evolution, from a common ancestral protoreceptor originated in a unicellular organism (Tasneem et al., 2004) or in a bilaterian ancestor (Xue, 1998; Tsang et al., 2006). This raises the possibility that members of this structurally related protein set might be widely present in living organisms including bacteria and primitive invertebrates. In the final part of last century, many studies provided evidence of the presence of $L G I C$ receptors in various invertebrate species, nematodes, molluscs, insects, often showing unconventional properties. Based on the available data, early studies grouped the Cys-loop LGIC receptors into two clades, the cationic AChR and serotonin receptors, and the anionic GABA/ glycine like receptors, whose divergence was estimated to have occurred at least 2500 million years ago (Ortells and Lunt, 1995). However, another phylogenetic analysis of the genome sequences of Caenorhabditis elegans and Drosophila melanogaster (Dent, 2006) only in part confirms these hypotheses. The study shows the existence of several LGIC families unique to invertebrates, suggesting that the major clades of the Cys-loop family likely diverged before the deuterostome/ecdysozoa split, and that many of these disappeared from chordates. Thus, evolution of contemporary phyla reveals a surprising loss of pentameric LGIC diversity in vertebrates (Dent, 2006; Dent, 2010).

The origin of cationic glutamate receptors may be equally ancient: a potassium channel activated by glutamate was discovered in prokaryotes, containing ligand-binding domains homologous to the eukaryotic glutamate receptors and the TVGYG sequence typical of potassium channels (Chen et al., 1999). Based on this and other findings, a recent study advances the hypothesis of a common origin of glutamate receptors and voltage-gated channels, whose ancestor could be traced in prokaryotes (Tikhonov and Magazanik, 2009).

The ancient origin of the LGIC receptor superfamily appears to precede the evolution of nervous systems, raising questions related to the functional roles of these proteins and to the mechanisms driving their diversification. Current analyses favor the view that the last common bilaterian ancestor may have evolved a large and diverse family of both metabotropic and LGIC chemoreceptors, later diverging in different phyla to gain additional functions (Cockcroft et al., 1990; Dent, 2006). The increasing availability of molecular data will help to better understand a crucial issue of neural development.

\section{Classical neurotransmitters in Hydra: or, absence of evidence is not evidence of absence}

Evidence for the presence of classical neurotransmitters in cnidarian nerves or tissues has accumulated from many mor- 
phological and functional studies, starting from the early sixties; however, owing to technical difficulties and to contradictory findings, a general disbelief about the occurrence and possible transmitter role of molecules such as acetylcholine, glutamate, GABA and glycine in cnidarians has long prevailed (Martin and Spencer, 1983). By contrast, the abundance of biogenic amines and different neuropeptides found in neurons of many hydrozoan and anthozoan species by histochemical, immunocytochemical, biochemical and molecular studies led to the assumption that in cnidarians neurotransmission was essentially aminergic and/or peptidergic, despite the lack of direct evidence of the involvement of these peptides in neurotransmission or neuromodulation. Since the topic has been extensively reviewed elsewhere (Kass-Simon and Pierobon, 2007), only two new contributions are briefly discussed here. Instead, given the focus on the occurrence of neurotransmitter ionotropic receptors in Hydra, this section will present old and new data on the biochemical and biological activities of selected LGICs and their ligands, namely acetylcholine, glutamate, GABA and glycine. Part of this work has also been reviewed in KassSimon and Pierobon (2007).

A recent survey of the genome of Nematostella vectensis for genes related to chemical transmission and hormonal signaling (Anctil, 2009) has produced a wealth of interesting results. Proteins related to aminergic transmission, receptors, enzymes, transporters, are heavily represented in the genome of Nematostella. Tyrosinase, dopa decarboxylase and monoamino oxidase transcripts with varying degrees of similarity to vertebrate sequences were found, together with different types of aminergic receptors. A tentative classification shows that some of the receptor transcripts present more similarity to dopaminergic and serotonergic, others to adrenergic or histaminergic, vertebrate and protochordate orthologues. By contrast, the abundant melatonin receptor transcripts present more similarity to other sea anemone transcripts.

RFamide-related transcripts were found, together with transcripts related to cnidarian peptides of other families and to vertebrate peptides (galanins, tachyinins, vasopressin, melanocortin and more). A larger number of transcripts corresponding to putative peptide receptors, outmatching their potential ligands, were also found. The represented neuropeptide families show a greater diversity than anticipated from current knowledge on cnidarian peptides. Furthermore in the phylogenetic tree, transcripts related to specific cnidarian peptides appear to be closer to invertebrate than to vertebrate counterparts; the opposite is true of transcripts related to non-peptidergic transmitters. It is interesting to note that the survey supports the conclusion of gene diversification and gene loss by descendants of the common ancestors of cnidarians and bilaterians, in agreement with the hypothesis advanced in other studies (Dent, 2006; Dent 2010).

Finally, a novel ion channel, directly gated by the neuropeptides Hydra-RFamides I and II, was recently cloned from Hydra and found expressed in epitheliomuscular cells at the base of the tentacles (Golubovic et al., 2007; Durrnagel et al., 2010). Homology searches show that this channel relates to members of the DEG/ EnaC gene family, that includes the only peptide gated-ionotropic receptor known to date, $\mathrm{FaNaC}$ from snails.

\section{Excitatory transmitters and receptors: acetylcholine}

Although acetylcholine (ACh) was one of the first substances to be tested for effects on the bioelectric activity in cnidarians (Ro- manes, 1885), evidence of its presence and biological role is scarce and controversial. ACh was found in desmoneme nematocysts of Hydrasp. (Castano andRossi, 1978). Acetylcholinesterase (AChE) reactivity was found in planula larvae of hydromedusae (Falugi et al., 1994), in nematocytes and hypostomal ganglion cells of Hydra (Lentz and Barrnett, 1961). Nicotinic AChR antagonists inhibited contraction bursts (CBs), the train of impulses that precedes ectodermal muscle contraction, while atropine, a muscarinic ACh antagonist, significantly increased them in Hydra (Kass-Simon and Passano, 1978). Exogenous ACh and cholinergic agonists were found to induce musclecontraction and nematocyst discharge (Lentz and Barrnett, 1962); however, the latter result was not confirmed by a later study (Scappaticci and Kass-Simon, 2008). AChE inhibitors were found to impair head regeneration (Lentz and Barrnett, 1963). ACh and choline esters increased the bioelectric activity of isolated muscle preparations from Bunodosoma (Mendes and Freitas, 1984); other studies failed to detect ACh, AChE and ChAT activity in other cnidarian species (van Marle, 1977; Scemes, 1989). Conversely, biochemical studies reported isolation and purification of choline acetyltransferase (ChAT) from Hydra (Erzen and Brzin, 1978) and from hydrozoan and anthozoan tissue homogenates (Talesa et al., 1992).

Interest for the biological role of acetylcholine has been revived by recent studies. AChE activity was found in the endoderm of tentacle bulbs, but not in the nervous system of Clytia hemisphaerica and three genes from the neuroligin-cholinesterase family were identified by BLAST search of a Clytia EST collection; enzyme activity was inhibited by physostigmine (Denker et al., 2008). A full length cDNA coding for AChE was cloned from Hydra magnipapillata (Takahashi et al., 2010); the HyAChE cRNA showed AChE activity in Xenopus oocytes and was expressed mainly in epithelial cells of the body column, but not in tentacles or basal disk. The authors conclude that their findings support a morphogenic role for ACh. However, it must be noted that, apart from western blot analysis, the study did not search for expression and localization of the corresponding protein; therefore, in my opinion, their conclusion should be regarded as temporary.

The analysis of the genome of Nematostella vectensis has found 20 sequences related to cholinergic functions, 3 ChATs, 5 AChEs and 12 nicotinic receptor subunits (Anctil, 2009). The presence of AChE and ChAT sequences in the Nematostella EST database suggests that these enzymes are expressed and potentially functional. The nicotinic receptor sequences show a range of $44-59 \%$ similarity to vertebrate and invertebrate nicotinic AChR subunits. The author concludes that all the proteins necessary for nicotinic neurotransmission are apparently present in the sea anemone, while transcripts of the muscarinic class could not be detected. Unfortunately, no data are available to date on the characterization of ACh receptor proteins in cnidarian systems. Although not conclusive, these new findings clearly indicate that research on cnidarian acetylcholine and its metabolic partners still is an open and promising field.

\section{Excitatory transmitters and receptors: glutamate}

Receptors to glutamate were discovered in Hydra vulgaris tissues twenty years ago. Binding studies show that glutamate binds to crude membrane fractions of Hydra (Bellis et al., 1991). The binding of $\mathrm{L}-\left[{ }^{3} \mathrm{H}\right]$ glutamate was rapid, reversible and saturable. A Scatchard analysis of the specific binding revealed values of 10 
$\mu \mathrm{M}$ for $\mathrm{K}_{\mathrm{D}}$ and $170 \mathrm{pmol} / \mathrm{mg}$ of protein for $\mathrm{B}_{\text {max }}$. About $65 \%$ of the specific $\mathrm{L}-\left[{ }^{3} \mathrm{H}\right]$ glutamate binding was inhibited by reduced glutathione (GSH) (Bellis et al., 1992). The remaining 35\% of the specific $\mathrm{L}-\left[{ }^{3} \mathrm{H}\right]$ glutamate binding was displaceable by the GluR agonists kainate and quisqualate but not NMDA, giving the first indication of a putative glutamate receptor in Hydra. The GSH-sensitive glutamate binding site presumably represents the association of glutamate with a putative GSH receptor, whose existence had been postulated by Lenhoff as early as 1961. Further work has shown specific $\left[{ }^{35} \mathrm{~S}\right] \mathrm{GSH}$ binding with $\mathrm{K}_{\mathrm{D}}$ values of $3.4 \mu \mathrm{M}$ and an $\mathrm{EC}_{50}$ value of $2.3 \mu \mathrm{M} \mathrm{GSH}$ (Grosvenor et al., 1992).

Following the discovery of strychnine-insensitive glycine binding sites in Hydra (Pierobon et al., 2001; see below), saturation experiments showed the presence of one population of binding sites with nanomolar affinity and low capacity for $\left[{ }^{3} \mathrm{H}\right] \mathrm{MK}-801$, a potent, noncompetitive antagonist of the NMDA receptor (Pierobon et al., 2004a). Before equilibrium, $\left[{ }^{3} \mathrm{H}\right] \mathrm{MK}-801$ binding was increased by the agonists glutamate and glycine as well as by GSH. These findings indicate that these receptors are functionally activated by their specific ligands; the ability of GSH to potentiate [ $\left.{ }^{3} \mathrm{H}\right] \mathrm{MK}-801$ binding is consistent with data obtained in rat (Ogita et al., 1995) and Hydra (Bellis et al., 1991) membrane preparations.

In Hydra, NMDAR, immunoreactivity localised both in nerve and effector cells, epitheliomuscular cells and nematocytes, where NMDA plays a role in nematocyst discharge, through activation of calcium fluxes (Scappaticci et al., 2004; Scappaticci and KassSimon, 2008). Preliminary reports localize AMPA- and kainate-like immunoreactivity in neurons and nematocytes of the tentacles (Kass-Simon and Scappaticci, 2004).

In vivo, glutamate and its agonists AMPA and kainate appeared to be generally excitatory in the ectodermal pacemaker systems of Hydra vulgaris, where their administration increased the frequency of contraction bursts (CBs) and tentacle pulses (TPs), the pacemaker systems responsible for body and tentacle contractions, respectively (Kass-Simon et al., 2003). The increase in CBs or TPs frequency was counteracted by the GluR antagonist NBQX (1,2,3,4-tetrahydro-6-nitro-2,3-dioxo-benzo[f]quinoxaline-7-sulfonamide), and potentiated by the lectin Con A, that prevents receptor desensitization in other systems (Evans and Usherwood, 1985). Association of the GluR agonist NMDA plus D-serine increased the frequency of TPs per se and in the presence of AMPA, but decreased the frequency of endodermal rhythmic potentials (RPs) induced by kainate; the ectodermal pacemaker system was not affected (Kay and Kass-Simon, 2009).

Apart from Hydra, where the glutamatergic system and its physiological activities have been studied in detail, very few data are available for other cnidarian species. Glutamate immunoreactivity was described in non-neuronal cells of the sea anemone Metridium senile, where, however, it has been considered a cell metabolite rather than a transmitter (Anctil and Carette, 1994). Martin (2004) reports that interneurons innervating the photoreceptors of the cubozoan Carybdea marsupialis label with anti-glutamate antibodies, as well as with antibodies made against serotonin, GABA and RFamide. A recent study reports glutamate immunoreactivity in the nerve plexus of the sea anemone Phymactis papillosa, where immunogold labeling localizes glutamate in neural processes (Delgado et al., 2010). Glutamate inhibits the electrical activity of the sphincter muscles in the sea anemone Tealia felina (Carlyle, 1974) but failed to affect the response of neurons of the motor nerve net of the scyphozoan jellyfish Cyanea capillata (Anderson and Trapido-Rosenthal, 2009).

Finally, a genomic analysis of the Nematostella database identified a large number of ionotropic GluRs, mainly AMPA-like and NMDA-like receptors. The AMPAorthologues show higher similarity to their bilaterian counterparts than NMDA orthologues. In addition, several members of the metabotropic GluR superfamily, together with calcium-sensing receptors, were detected (Anctil, 2009). The author suggests that the large number of glutamate-related sequences hints at an important role of glutamic acid as a transmitter, with a possible diversity of responses, in the sea anemone.

\section{Inhibitory transmitters and receptors: GABA and glycine}

Evidence of the occurrence of $\gamma$-amino butyric acid (GABA) and its cellular localization in Hydra has proven exceedingly difficult to obtain. Agas chromatography/mass spectrometry analysis of tissue homogenates revealed the presence of three fragmentation peaks perfectly coincident with those obtained from synthetic GABAat the same time of elution; this result was reproduced with two different derivatization methods (Pierobon, unpublished). However, at the time, we considered these findings inconclusive, since we were not able to confirm these data by HPLC and to observe convincing GABA immunoreactivity in Hydra cryosections, so that we could not exclude a possible bacterial origin of GABA. Therefore, we chose a different experimental approach.

Receptors to GABA were identified in membrane preparations from Hydra vulgaris (Pierobon et al., 1995). The binding of $\left[{ }^{3} \mathrm{H}\right]$ GABAwas specific (70\% specific binding), reversible and saturable. A Scatchard analysis of saturation data indicated the presence of only one population of binding sites with high affinity $\left(\mathrm{K}_{\mathrm{D}}=76 \mathrm{nM}\right)$ and low capacity $\left(B_{\max }=4.75 \mathrm{pmol} / \mathrm{mg}\right.$ of protein). $\left[{ }^{3} \mathrm{H}\right] \mathrm{GABA}$ binding was completely inhibited by the GABA agonist muscimol and by the $\mathrm{GABA}_{\mathrm{A}}$ receptor antagonist gabazine, whereas bicuculline was ineffective; baclofen, a $\mathrm{GABA}_{\mathrm{B}}$ receptor antagonist, weakly $(>30 \%)$ inhibited $\left[{ }^{3} \mathrm{H}\right] \mathrm{GABA}$ binding. The apparent insensitivity to bicuculline and baclofen shown in competition experiments, similar to other invertebrate findings, suggested that these receptors were a primitive, early evolved, protein class.

Later studies revealed that Hydra receptor proteins exhibited a complex pharmacological profile (Concas et al., 1998; Pierobon et al., 2004b). The neuroactive steroids allopregnanolone ( $3 \alpha-$ hydroxy-5 $\alpha$-pregnan-20-one; THP) and tetrahydrodeoxycorticoste-

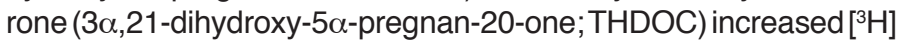
GABA binding to Hydra membranes with nanomolar potency and high efficacy, whereas the $3 \beta$-hydroxy epimer of allopregnanolone was ineffective. The benzodiazepine (BZ) receptor ligands diazepam, clonazepam and abecarnil enhanced [ $\left.{ }^{3} \mathrm{H}\right] \mathrm{GABA}$ binding to hydra membranes by $20 \%-24 \%$, effects abolished by the specific central BZantagonist flumazenil. On the contrary, the peripheral BZ receptor ligand 4'chlorodiazepam failed to affect [ $\left.{ }^{3} \mathrm{H}\right] \mathrm{GABA}$ binding to Hydramembranes. Alphaxalone (3-hydroxypregnane-11,20-dione), barbiturates, and propofol similarly increased [ $\left.{ }^{3} \mathrm{H}\right] \mathrm{GABA}$ binding. The modulation of $\mathrm{GABA}_{A}$ receptors by these various drugs in vitro correlated with their effects on the GSH-induced response in the living animals (see below). These pharmacological findings indicate that multiple binding sites exist on the Hydra GABA receptors, suggesting that they may be comprised of different subunits, at least $\alpha \beta \gamma$ and $\delta$ subunits, whose biochemical and pharmacological 
properties compare with those of their mammalian counterparts. In vivo, GABA and its positive allosteric modulators were shown to decrease the frequency of $\mathrm{CBs}$, the ectodermal pacemaker system, (GABA) and of RPs, the endodermal rhythmic potentials system (GABA, muscimol, diazepam); none of the ligands affected TPs frequency, i.e. tentacle activity. Interestingly, the inhibitory action of GABA was suppressed by bicuculline, per se ineffective (KassSimon et al., 2003). GABA and the metabotropic $G_{A B A} R$ agonist baclofen significantly increased the rate of distant desmoneme discharge, by acting through $\mathrm{GABA}_{\mathrm{B}}$ receptors in Hydra tentacles (Scappaticci and Kass-Simon, 2008).

Several authors reported negative results in biochemical, morphological and functional studies of Hydra and other cnidarian species, (Gitter et al., 1994; Anctil and Minh, 1997; reviewed in Grimmelikhuijzen et al., 1996, 2002). More recently, GABA immunoreactivity was found in interneurons of the cubozoan jellyfish Carybdea marsupialis (Martin, 2004) and in the ectodermal nerve net of the anthozoan sea anemone Nematostella vectensis (Marlow et al., 2009). GABA immunogold labelling was found in putative neural processes within the neural plexus of the sea anemone Phymactis papillosa (Delgado et al., 2010). A recent study reported identification of GABA by HPLC and immunocytochemical localization of related molecules, the synthesizing enzyme glutamic acid decarboxylase, the vesicular GABA transporter, and one of the GABA receptors, the metabotropic $\mathrm{GABA}_{\mathrm{B}}$ receptor, in neuronal and non neuronal cells of the sea fan Eunicella cavolini (Girosi et al., 2007).

Following the characterization of GABA receptors, the occurrence of receptors to glycine, another inhibitory amino acid neurotransmitter in vertebrate nervous system, was investigated in Hydra vulgaris. We reported the identification and characterisation of the first invertebrate glycine receptor, whose biochemical and pharmacological properties also compare with those of vertebrate GlyRs (Pierobon et al., 2001). Saturation experiments revealed the existence of one population of binding sites for $\left[{ }^{3} \mathrm{H}\right]$ strychnine of nanomolar affinity $\left(\mathrm{K}_{\mathrm{D}}=33 \mathrm{nM}\right)$ and low capacity $\left(\mathrm{B}_{\max }=79 \mathrm{fmol} /\right.$ $\mathrm{mg}$ protein). The addition of glycine or taurine $(0.1 \mu \mathrm{M}$ to $1 \mathrm{mM})$ produced a dose-dependent inhibition of $\left[{ }^{3} \mathrm{H}\right]$ strychnine binding. $\beta$-alanine, a partial glycine agonist, did not significantly affect $\left[{ }^{3} \mathrm{H}\right]$ strychnine binding at the same concentrations. $\left[{ }^{3} \mathrm{H}\right]$ strychnine binding was not displaced by D-serine, a glycine agonist at the glycinergic binding site of NMDA receptors (Mothet et al., 2000).

In the living polyp, the administration of D-serine reduced the duration of $\mathrm{GSH}$-induced mouth opening suggesting the presence of strychnine-insensitive binding sites (Pierobon et al., 2001). Extracellular electrophysiological experiments have shown that glycine and taurine, acting on strychnine-sensitive receptors, decreased the endodermal rhythmic potentials (RPs); in addition, glycine per se significantly decreased both the rate of CBs and the number of impulses per contraction burst (P/CB). However, in the presence of strychnine-insensitive site blockers, this effect was suppressed, suggesting that glycine acts on the ectodermal pacemaker system through the glycine-binding site of the NMDA receptor (Ruggieri et al., 2004). The dual action of glycine observed in behavioral and electrophysiological experiments led to the characterization of NMDA receptors (see above).

These findings are not isolated. Carlberg et al., (1995) found taurine-like immunoreactivity in the motor nerve net of the jellyfish Cyanea capillata. Anctil and Minh (1997) demonstrated taurine- like immunoreactivity in the peri-oral subectodermal nerves and the zooid nerve net of the endodermal retractor muscle of Renilla koellikeri, suggesting a possible role as a neuromuscular transmitter. Nakanishi et al., (2009) found taurine immunoreactivity in sensory cells of the rhopalial nerve net in Aurelia. Taurine and $\beta$-alanine, together with GABA, glycine, glutamate and aspartate, are present in the free amino acid pool of neurons of the motor nerve net of Cyanea capillata, from which they are released by depolarization; however, when applied on neuron preparations, only taurine and $\beta$-alanine produced a response, namely a large depolarization followed by conductance change (Anderson and Trapido-Rosenthal, 2009). Thus in Cyanea, taurine and partly $\beta$ alanine act as excitatory transmitters at bidirectional synapses in the motor nerve net (Anderson and Grunert, 1988). The discrepancy between these results and our observations (in our experiments taurine acted as a typical GlyR agonist, both in behavioural and electrophysiological studies) cannot be satisfactorily explained on the basis of the available evidence. However, it is interesting to note that glycine receptors change their binding characteristics by point mutations in a variety of pathological conditions, such as inherited neurological disorders. In fact, substituting arginine 271 with either leucine or glutamine by site-directed mutagenesis transforms taurine and $\beta$-alanine from agonists into competitive antagonists (Rajendra et al., 1995).

Finally, both $\mathrm{GABA}_{\mathrm{A}}$ and $\mathrm{GABA}_{\mathrm{B}}$ receptors, and one glycine receptor were found in the genome of Nematostella. GABA sequences are more abundant, but they appear to be distantly related to their vertebrate orthologues; the difference in structure is also reflected by the lack of several residues important for GABA binding; by contrast, GABA $\mathrm{B}_{\mathrm{B}}$ and GlyR transcripts show a higher degree of similarity (Anctil, 2009). These results are not consistent with the biochemical and pharmacological data obtained in Hydra vulgaris. It is possible that a survey of the Hydra genome might eventually draw a different picture; on the other hand, gene diversity and/or gene loss may be already observable within Cnidaria. Future studies, primarily the molecular characterization of GABA receptor genes in Hydra, are clearly needed in order to reach a better understanding of this controversial issue.

In conclusion, $\mathrm{ACh}$ and glutamate seem to play an excitatory role in Hydra, while GABA and glycine seem to be inhibitory, in keeping with the known biological activity of vertebrate neurotransmitters. At least two molecules, glutamate and GABA, act on nematocyte effectors, by increasing the rate of nematocyst discharge, while glycine and likely ACh are not effective. All substances, ACh, glutamate, GABA and glycine, modulate myoneme effectors, possibly acting on intermediate neurons. Evidence of neuronal localization is at present only available for glutamate and NMDA.

$\mathrm{ACh}$ and cholinergic agonists show an excitatory role, in that they induce muscle contraction, acting on both the ectodermal and endodermal pacemaker systems. Glutamate and its agonists AMPA and kainate display an excitatory role on body contraction and tentacle pulses; they also increase the frequency of endodermal rhythmic potentials. However another GluR agonist, NMDA, specifically increases tentacle activity, but inhibits the endodermal pacemaker system.

GABA has an inhibitory role on muscle contraction, by reducing the frequency of both ectodermal CBs and endodermal RPs, but does not significantly affect electrical activity of the tentacles. Finally glycine plays a dual role on contraction and elongation of 
the body column, in that it has inhibitory effects on the endodermal pacemakers, and may be potentially excitatory on the ectodermal pacemaker system through its effects on the glycine site of the NMDA receptor (see Ruggieri et al., 2004, for discussion).

Since intracellular recording data are not available, and the actual sites affected by treatment cannot be identified, these results rather reflect a composite effect of drugs on muscular and multiple neuronal effectors. In particular, glutamate and glycine acting on selective receptor types may cause opposing effects on the coordinating systems of body and tentacles. Future studies will help to obtain a more detailed picture of the role of these substances in Hydra.

\section{The Hydra feeding response}

Hydra polyps feed through a complex behavioral pattern prompted by prey capture. Tentacles sense vibrations of nearby swimming prey through mechanoceptors; chemical stimulants also concur to recognition of prey. This leads to activation of nematocytes, which discharge the nematocyst tubule into the prey, capturing and paralyzing it onto the tentacles. GSH, outflowing from the wounded prey, stimulates the opening of a mouth. Preyloaded tentacles bring the prey into the mouth, where it is finally ingested. Part of the response, tentacle writhing and mouth opening, can be produced in vitro by polyps' exposure to GSH, which is the specific stimulant of the feeding behavior in Hydra as well as in other cnidarian species (Loomis, 1955; Lenhoff, 1961). Lenhoff $(1974,1977)$ described in detail the kinetics of the response to $\mathrm{GSH}$, advancing the hypothesis that a specific chemoreceptor mediated this response. Later, two independent groups reported the occurrence and characterization of a GSH receptor population in Hydra tissues (Venturini, 1987; Grosvenor et al., 1992).

Several studies contributed to confirm and clarify several aspects of this model. Different steps of the feeding response (tentacle concert, tentacle writhing) are suppressed by monoclonal antibodies that bind to the cnidocil complex of tentacle nematocytes, suggesting that these antibodies may be directed against structural components involved in mechano- and/or chemotransduction (Golz andThurm, 1992; Ohta et al., 1992). GABA and NMDA respectively increase the rate of discharge of desmoneme and stenotele nematocytes, originally considered independent functional units, suggesting a neural regulation of tubule discharge (Scappaticci andKass-Simon, 2008). Previous studies had shown that discharge of stenotele nematocytes is voltage- and $\mathrm{Ca}^{2+}$-dependent (Gitter et al., 1994).

Upon GSH stimulation, CBs pacemaker activity and body contractions are inhibited, tentacle movements become convulsive and TPs are also inhibited, while endodermal RPs are not affected (Rushforth and Hofman, 1972); a mouth opens abruptly. Formation and opening of the mouth, that is normally undetectable in nonstimulated polyps, are ultimately attained by coordinated contraction and relaxation of myofibrils embedded in the ectodermal and endodermal epithelial cells of the head (Campbell, 1987; Technau and Holstein, 1995) mediated by electrical synapses (Hufnagel and Kass-Simon, 1976).

Transduction of the GSH signal relies on second messengers, whose identification is still quite controversial. Cobb et al., (1980) report an increase of both cGMP and CAMP levels in the presence of $\mathrm{GSH}$, but exclude a direct or indirect action of cyclic nucleotides on the feeding behavior. Dopamine increases cAMP levels, prolong- ing duration of the response to GSH (Venturini and Carolei, 1992). Elevated nitric oxide (NO)-induced cGMP levels are able to trigger inhibition of the response to GSH, presumably via cGMP-activated protein kinases (Colasanti et al., 1997). A widespread distribution of NADPH-diaphorase reactivity, a marker of NO synthase, was found in nerves of the body column but not of tentacles of Hydra vulgaris (Cristino et al., 2008). The NO pathway is also involved in triggering nematocyst discharge in the sea anemone Aiptasia diaphana, where NO synthase localizes in acontial tissue surrounding nematocytes (Salleo et al., 1996). Furthermore, the anatomical pathways leading from mechano-and chemoreceptors to the effector cells involved are only in part identified. Recent studies show that hydrozoan nematocytes send and receive synaptic signals upon mechano-chemical stimulation, acting as bimodal sensory cells (Thurm et al., 2004; Oliver et al., 2008).

The feeding behavior is interrupted upon GSH removal, but the mechanisms by which termination of the response is achieved are still poorly understood. Lenhoff (1974) suggested that mouth closure simply derived from receptor desensitization, or unbinding of GSH from its receptor. This hypothesis was challenged by the finding that wounded prey release other substances, as well as $\mathrm{GSH}$, that are able to shorten response duration by competitive inhibition of GSH binding (Grosvenor etal., 1996). Our group found that inhibitory and excitatory amino acid transmitters modulate the feeding behavior by prolonging or shortening, respectively, the duration of the response to GSH.

\section{The $\gamma$-glutamil-cysteinyl-glycine (GSH) assay}

The GSH assay is a simple and reliable model for the study of chemoreception. Onset of response, i.e. opening of the mouth is very fast (seconds) and occurs within 1 - 2 minutes after GSH administration; mouth closure is a slower process, and occurs 20 to 25 minutes at $10 \mu \mathrm{M}$ GSH. Duration of the response, i.e. the time interval between mouth opening and mouth closure, is linearly related to the stimulus intensity in the low micromolar GSH concentration range and can be easily measured, providing a quantitative parameter for process evaluation.

In the presence of GABA, glycine, and their agonists, the mouth opens in 1 to 2 minutes upon GSH stimulation, with no difference with respect to controls, but mouth closure is delayed, resulting in a significant increase of response duration. Conversely NMDA, a GluR agonist, significantly reduces response duration by anticipating times of mouth closure, but does not affect times of mouth opening; glutamate, AMPA and kainate, that prevent mouth opening, could not be used in the GSH assay. These data suggest that amino acid transmitters, presumably acting on the cellular circuitry involved, regulate part of the response activated by GSH. The action of transmitters is exerted through their specific receptors, identified and characterized by binding experiments.

Administration of $100 \mu \mathrm{M}$ GABA significantly increased the duration of mouth opening induced by GSH. Prolonged exposure to the ligand suppressed the effect, suggesting receptor desensitization. As predicted from biochemical experiments, GABA ${ }_{A} R$ agonists and positive allosteric modulators mimicked or potentiated these effects of GABA in a dose-dependent manner. The specific GABA agonist $_{B}$ baclofen did not significantly modify duration of the GSH-induced response (Pierobon et al., 1995; Concas et al., 1998).

The classical $\mathrm{GABA}_{\mathrm{A}}$ receptor antagonist bicuculline, per se 
inactive, was able to suppress the GABA-induced increase in response duration. Another $\mathrm{GABA}_{A}$ receptor antagonist, gabazine, suppressed the effects of GABA and GABA agonists in a 1-10 $\mu \mathrm{M}$ concentration range; in the absence of GABA, it shortened response duration. The specific $\mathrm{Cl}^{-}$channel blockers, picrotoxin $(10 \mu \mathrm{M})$ and TBPS $(1 \mu \mathrm{M})$, which per se shortened the duration of the response, also abolished the increase in response duration induced by GABA and counteracted the effects of muscimol, neurosteroids and general anesthetics. These results are summarized in Table 1, Fig. 3.

Taken together, these data indicate that in the living polyp GABA modulates duration of the feeding response acting through $\mathrm{GABA}_{\mathrm{A}}$-like receptors: in fact, both ligand binding and channel gating pharmacological properties are typical of canonical GABA $A$ R. Furthermore, these results suggest that receptor subpopulations of different subunit composition may be present, with varying degrees of affinity for specific agonists and antagonists. Finally, the finding that the GSH response is shortened by gabazine and by $\mathrm{Cl}^{-}$channel blockers suggests a role of endogenous GABA in modulation of the response in physiological conditions.

A significant increase in the duration of mouth opening was also obtained in the presence of glycine, taurine or $\beta$-alanine. The enhancement of the response was related both to amino acid (10-100 $\mu \mathrm{M})$ and to GSH concentration (1-10 $\mu \mathrm{M})$. The effects of glycine or its agonists were suppressed by the GlyR antagonist strychnine (1-10 $\mu \mathrm{M})$ and by picrotoxin (1-10 $\mu \mathrm{M})$ (Pierobon et al., 2001). However, glycine, but not taurine, reduced duration of mouth opening when all the strychnine-sensitive binding sites were blocked by $10 \mu \mathrm{M}$ strychnine; this effect was mimicked by D-serine. The effects of D-serine were suppressed by the antagonist DCKA (5,7-dichlorokynurenic acid) but not by strychnine (Table 2, Fig. 4). In fact, in the presence of DCKA, the administration of glycine plus high strychnine increased the duration of mouth opening by $40 \%$, increase significantly higher than control animals, but also

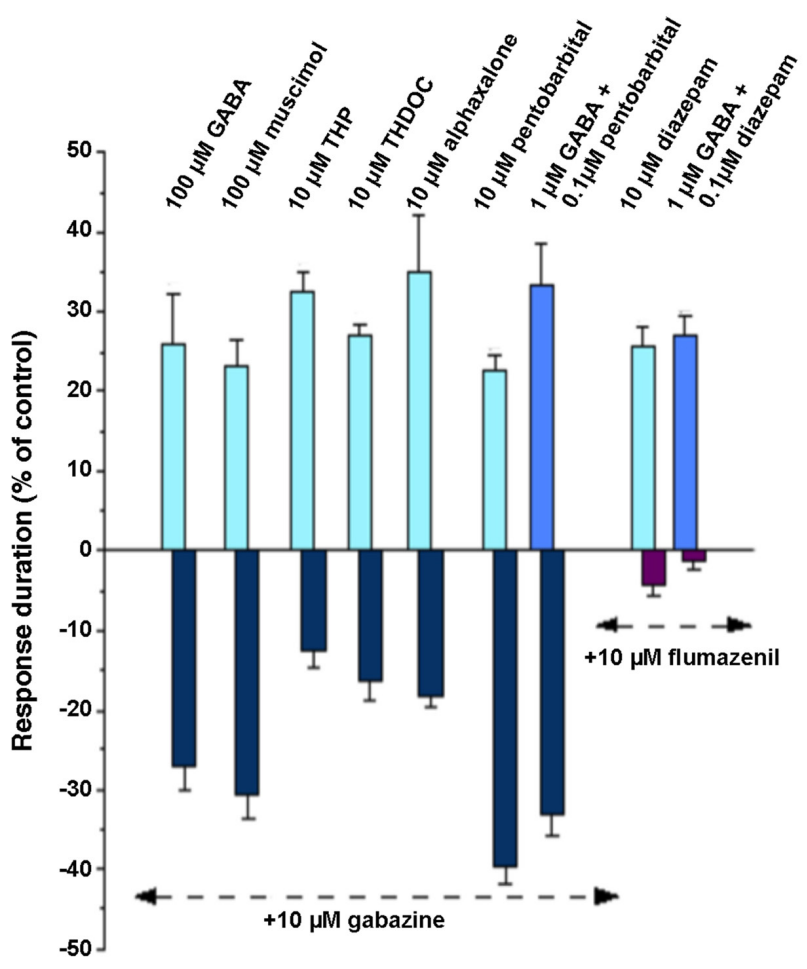

TABLE 1

\section{EFFECTS OF GABA AGONISTS AND ANTAGONISTS ON THE DURATION OF THE RESPONSE TO GSH}

\begin{tabular}{|c|c|c|c|}
\hline \multicolumn{2}{|c|}{ AGONISTS } & \multicolumn{2}{|c|}{ ANTAGONISTS } \\
\hline & & $+1 \mu \mathrm{M}$ TBPS & $+10 \mu \mathrm{M}$ gabazine \\
\hline solvent & $100 \%$ & $-31.5 \% \pm 4.1$ & $-22.8 \% \pm 3.5$ \\
\hline $100 \mu \mathrm{M}$ GABA & $+25.7 \% \pm 6.4$ & $-23.5 \% \pm 2.5$ & $-27.1 \% \pm 3.1$ \\
\hline $100 \mu \mathrm{M}$ muscimol & $+23.1 \% \pm 3.1$ & $-25.7 \% \pm 2.5$ & $-30.7 \% \pm 2.7$ \\
\hline $10 \mu \mathrm{M}$ THP & $+32.3 \% \pm 2.5$ & $+2.9 \% \pm 1.1$ & $-12.6 \% \pm 2.3$ \\
\hline $10 \mu \mathrm{M}$ THDOC & $+26.9 \% \pm 1.3$ & $-16.7 \% \pm 2.4$ & $-16.5 \% \pm 2.1$ \\
\hline $10 \mu \mathrm{M}$ alphaxalone & $+34.6 \% \pm 7.5$ & $+4.8 \% \pm 1.9$ & $-18.5 \% \pm 1.0$ \\
\hline $10 \mu \mathrm{M}$ pentobarbital & $+22.4 \% \pm 1.9$ & & $-39.8 \% \pm 2.3$ \\
\hline \multirow{2}{*}{$\begin{array}{c}1 \mu \mathrm{M} \text { GABA + } \\
0.1 \mu \mathrm{M} \text { pentobarbital }\end{array}$} & $+33.2 \% \pm 5.1$ & & $-33.3 \% \pm 2.8$ \\
\hline & & & $+10 \mu \mathrm{M}$ flumazenil \\
\hline $10 \mu \mathrm{M}$ diazepam & $+25.5 \% \pm 2.4$ & & $-4.5 \% \pm 1.1$ \\
\hline $\begin{array}{c}1 \mu \mathrm{M} \text { GABA + } \\
1 \mu \mathrm{M} \text { diazepam }\end{array}$ & $+26.8 \% \pm 2.5$ & & $-1.6 \% \pm 1.0$ \\
\hline
\end{tabular}

GABAand muscimol significantly increase duration of the response to GSH, the increase is suppressed by gabazine or by $\mathrm{Cl}^{-}$channel blockers TBPS (GABA) and $10 \mu \mathrm{M}$ PTX (muscimol). Neurosteroids, pentobarbital, and diazepam, also increase response duration, potentiating the action of GABA. Their effects are suppressed by GABA antagonists. Data are presented as mean percentage variation \pm SEM of control (10 $\mu \mathrm{M}$ GSH). See corresponding graph in Fig. 3.

of animals treated with the corresponding dose of glycine alone. Thus glycine also appears to be involved in modulation of the feeding behavior, acting both on ionotropic GlyRs, as shown by picrotoxin, with a presumed inhibitory action, and on the glycine binding site of putative NMDA receptors, whose action could be excitatory.

The dual action of glycine in Hydratissues suggested that NMDA receptors might also be present in Hydra, and implicated in the modulation of the feeding behavior. Accordingly, the GluR agonist NMDA markedly decreased the duration of the response to GSH. This effect was linearly related to ligand doses in the nanomolar concentration range and was counteracted by either the NMDAR specific antagonist D-AP5 (D-(-)-2 amino-5-phosphopentanoic acid) or by the D-serine antagonist DCKA. When NMDA concentration was increased to 10 or $100 \mu \mathrm{M}$, duration of the response to GSH was no longer affected unless Con A was added to the test medium. Simultaneous administration of ineffective doses of NMDA and strychnine, glycine or D-serine, resulted in a strong reduction of response duration. Both D-AP5 and DCKAsuppressed this effect (Table 2, Fig. 4) (Pierobon et al., 2004a).

In order to investigate the contribution of endogenous amino acids to the GSH response, polyps were exposed to depolarizing pulses of $56 \mathrm{mM} \mathrm{KCl}$ or $1 \mu \mathrm{M}$ veratridine. In these conditions, the animals retained the ability to perceive the GSH stimulus and to react appropriately. However, the magnitude of the response was significantly reduced. GABA and its agonist muscimol were able to restore or to enhance duration of the response in stressed

Fig. 3. Effects of GABA agonists (GABA, muscimol, THP, THDOC, alphaxalone, pentobarbital, diazepam) and GABA antagonists (gabazine, flumazenil) on the response to $\gamma$-glutamil-cysteinyl-glycine (GSH). GABA and muscimol significantly increase the duration of the response to $\mathrm{GSH}$, the increase is suppressed by gabazine or by $\mathrm{Cl}$ - channel blockers TBPS (GABA) and 10 $\mu$ M PTX (muscimol). Neurosteroids, pentobarbital, and diazepam, also increase response duration, potentiating the action of GABA. Their effects are suppressed by GABA antagonists. Data are presented as mean percentage variation \pm SEM of control (10 $\mu \mathrm{M}$ GSH, see Table 1). 
TABLE 2

\section{EFFECTS OF GLYCINE, TAURINE, $\beta$-ALANINE, STRYCHNINE, NMDA, D-SERINE, AND NMDA ANTAGONISTS, ON THE DURATION OF THE RESPONSE TO GSH}

\begin{tabular}{|c|c|c|c|}
\hline \multicolumn{2}{|c|}{ AGONISTS } & \multicolumn{2}{|c|}{ ANTAGONISTS } \\
\hline & & $+10 \mu \mathrm{M}$ PTX & $+10 \mu \mathrm{M}$ strychnine \\
\hline solvent & $100 \%$ & $-18.1 \% \pm 4.7$ & $-4.8 \% \pm 3.4$ \\
\hline $100 \mu \mathrm{M}$ glycine & $+22.1 \% \pm 1.5$ & $-1.8 \% \pm 3.6$ & $-18.6 \% \pm 2.9$ \\
\hline $100 \mu \mathrm{M}$ taurine & $+26.5 \% \pm 3.0$ & $-6.1 \% \pm 7.6$ & $+4.5 \% \pm 4.1$ \\
\hline $100 \mu \mathrm{M}$ ßalanine & $+25.0 \% \pm 2.8$ & $+3.5 \% \pm 4.2$ & $-0.2 \% \pm 3.0$ \\
\hline \multirow{3}{*}{$\begin{array}{c}100 \mu \mathrm{M} \text { glycine + } \\
0.1 \mu \mathrm{M} \text { DCKA }\end{array}$} & $+39.7 \% \pm 3.5$ & & $+5.2 \% \pm 1.5$ \\
\hline & & $+0.1 \mu \mathrm{M}$ DAP5 & $+0.1 \mu \mathrm{M}$ DCKA \\
\hline & & $+0.1 \% \pm 5.1$ & $-0.4 \% \pm 6.1$ \\
\hline $100 \mu \mathrm{M}$ D-serine & $-35.1 \% \pm 1.6$ & $+2.7 \% \pm 3.3$ & $+0.4 \% \pm 2.7$ \\
\hline $0.1 \mu \mathrm{M}$ NMDA & $-1.2 \% \pm 5.3$ & & \\
\hline $\begin{array}{l}0.1 \mu \mathrm{M} \text { NMDA + } \\
0.1 \mu \mathrm{M} \text { D-serine }\end{array}$ & $-39.9 \% \pm 4.3$ & $+0.1 \% \pm 5.1$ & $-0.4 \% \pm 6.1$ \\
\hline $0.1 \mu \mathrm{M}$ NMDA+ Con $A$ & $-19.1 \% \pm 1.0$ & $0.0 \% \pm 1.0$ & \\
\hline $1 \mu \mathrm{M}$ NMDA & $-22.7 \% \pm 2.3$ & $-3.4 \% \pm 0.7$ & $-2.5 \% \pm 0.9$ \\
\hline $1 \mu \mathrm{M}$ NMDA + Con A & $-39.8 \% \pm 5.1$ & $+4.9 \% \pm 2.4$ & \\
\hline
\end{tabular}

Glycine, taurine, $\beta$-alanine significantly increase response duration; the increase is suppressed by PTX and by strychnine. The significant decrease of response duration observed in the presence of $10 \mu \mathrm{M}$ strychnine plus $100 \mu \mathrm{M}$ glycine is suppressed by the specific NMDA antagonist DCKA. NMDA significantly reduces response duration. The action of NMDA is potentiated by Con A $(27 \mu \mathrm{g} / \mathrm{ml})$ and by the co-agonist D-serine, per se also shortening the response at higher doses. Both DAP5 and DCKA counteract the effects of NMDA and D-serine. Data are presented as mean percentage variation \pm SEM of control (10 $\mu \mathrm{M}$ GSH). See corresponding graph in Fig. 4.

animals in a dose-dependent manner, while glycine and taurine did not counteract the decrease in response duration. Gabazine suppressed the effects of GABA and muscimol (Pierobon et al., 2004b). These results support the conclusion that GABA appears to be the major inhibitory transmitter involved in the regulation of the feeding response, and that GABA and glycine act by different pathways.

\section{Problems and perspectives}

The finding that GABA and glycine do not modify the time interval between GSH administration and opening of the mouth suggests that these molecules are not interfering with the GSH transduction pathway but may rather be acting on myofibril effectors. Alternatively, electrophysiological data support the hypothesis that at least GABA could act synergistically with the GSH stimulus, reinforcing inhibition of ectodermal and endodermal pacemaker systems. In addition GABA, acting through its metabotropic receptor, could serve a chemosensory role in the initial steps of the feeding behavior. Termination of the response, then, could result from of a coordinated interplay of different sets of target

Fig. 4. Effects of glycine, taurine, $\beta$-alanine, strychnine, NMDA, D-serine, and NMDA antagonists, on the response to $\gamma$-glutamil-cysteinyl-glycine (GSH). Glycine, taurine, $\beta$-alanine significantly increase response duration; the increase is suppressed by PTX and by strychnine. The significant decrease of response duration observed in the presence of $10 \mu \mathrm{M}$ strychnine plus 100 $\mu \mathrm{M}$ glycine is suppressed by the specific NMDA antagonist DCKA. NMDA significantly reduces response duration. The action of NMDA is potentiated by Con $A(27 \mu \mathrm{g} / \mathrm{ml})$ and by the co-agonist D-serine, per se also shortening the response at higher doses. Both DAP5 and DCKA counteract the effects of NMDA and D-serine. Data are presented as mean percentage variation \pm SEM of control (10 $\mu \mathrm{M}$ GSH, see Table 2). cells (neurons?) that regulate muscle contraction and relaxation.

The mechanisms of action of glycine and glutamate are more difficult to understand, and more information should be gathered in order to draw a reliable picture. Glycine, like NMDA, exerts both an inhibitory role on endodermal RPs and an excitatory role on ectodermal pacemakers, but, differently from NMDA, does not affect tentacle activity; its action could be tentatively attributed to differential modulation of neural intermediates involved in the effector response to GSH stimulation or in the GSH transduction pathway. Studies directed at identifying the cellular localization of the different glycine binding sites are clearly needed to begin to solve the riddle.

Glutamate and GluR agonists appear to act in all stages of the feeding behavior, with multiple mechanisms of action. Glutamate and its iGluR agonists modulate the rate of nematocyst discharge, possibly acting with a chemosensory role. Glutamate prevents the GSH-induced mouth opening in vivo, but does not displace the specific binding of radiolabeled GSH, and must therefore block the feeding response by a mechanism other than competitive inhibition. An effect of glutamate on metabotropic GluRs, not yet identified in Hydra, could not be excluded in principle. It is interesting to note that a taste receptor, the vertebrate umami receptor, is a metabotropic glutamate receptor variant (Chaudhari et al., 2000). Conversely GSH binds to GluRs or potentiates NMDA binding in vitro. It is tempting to speculate that the putative Hydra GSH receptor may belong to an ancestral class of sensory chemoreceptors, distributed on the ectodermal epithelial cell membranes of the polyp, and later evolved to serve different or additional functions. A possible role of glutathione as a new neurotransmitter and/or neuromodulator, in addition to its well-known cellular anti-oxidant actions, has been repeatedly proposed (Ogita et al., 1995; Shaw, 1998; Janaky et al., 2000). Finally, glutamate and its iGluR agonists modify the electrical activity of ectodermal and endodermal pacemaker systems with effects opposite to GSH; accordingly, at

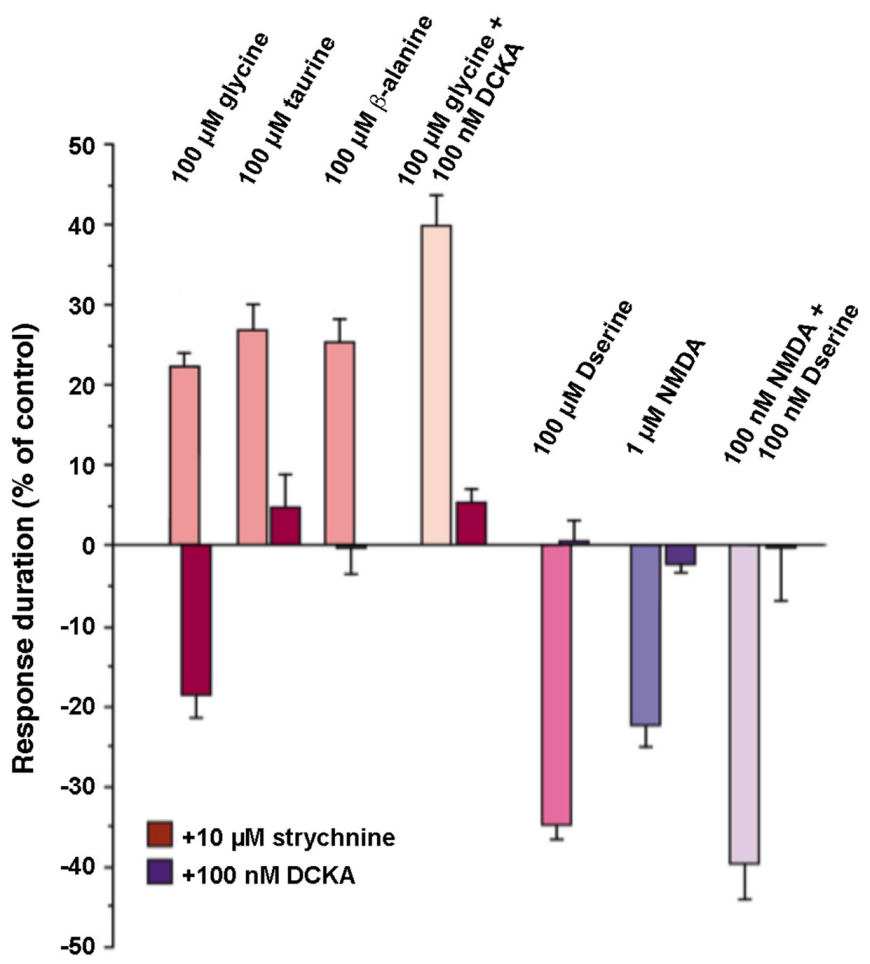


A
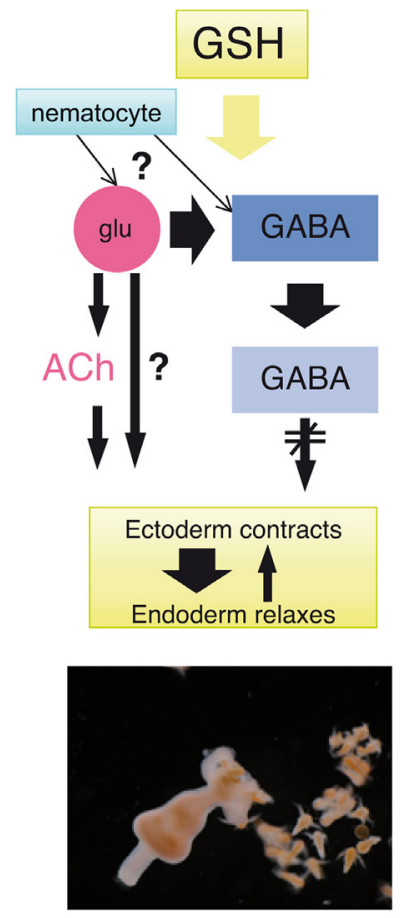

B

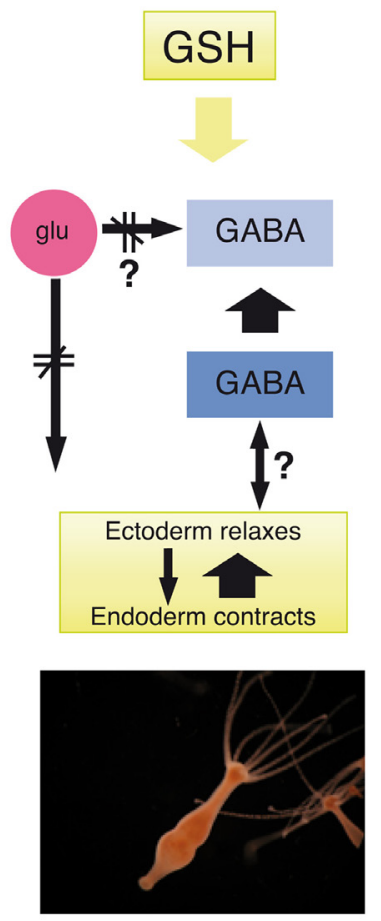

Fig. 5. A working model of the hypostomal circuitry regulating the feeding response and its cessation in Hydra. (A) Mechanisms controlling mouth opening. Upon exogenous GSH stimulation, and possibly upon concurrent afferent synaptic signals from discharged nematocytes, a glutamatergic pathway is activated. Multipolar glutamatergic neurons stimulate the ectodermal pacemakers, either directly or via cholinergic neurons. They simultaneously stimulate a GABAergic pathway comprised of at least two interneurons (ganglion cells?), whose inhibitory input on the mouth ectoderm is thus suppressed. As a result of this combined stimulation, the ectodermal myofibrils of the mouth contract, and the endodermal myofibrils relax: the mouth opens. (B) Termination of the feeding behavior. In time, the endodermal rhythmic potential (RP) pacemaker overrules the contraction burst (CB) pacemaker, the ectodermal epithelial cells no longer responding to GSH/transmitter stimulation. Furthermore, transmitter reuptake by the GABAergic interneuron(s) blocks the GABAergic pathway, resuming inhibition of the ectoderm muscles. The endodermal myofibrils contract, while the ectodermal myofibrils slowly relax: the mouth closes. In the presence of exogenous GABA, the GABAergic pathway is potentiated: prolonged stimulation of GABAergic interneurons increases duration of the contractions of ectodermal myofibrils, opposing the activation of $\mathrm{RP}$ pacemakers, and therefore delaying mouth closure. In the presence of exogenous NMDA, concomitant activation of glutamatergic neurons by GSH signals and NMDA may result in overstimulation, anticipating onset of refractory state and/or receptor internalization, thus reducing the efficacy of the GSH stimulus. As a consequence, the duration of ectodermal contraction and therefore of mouth opening is shortened. Alternatively, a second inhibitory pathway, as yet not identified, may be activated by NMDA. Finally, other neuronal subsets reacting to different gluR agonists might concur to the overall response to GSH.

least one of the GluR agonists, NMDA, shortens duration of the response. The neuronal localization of NMDAR immunoreactivity supports the hypothesis that glutamatergic neurons play a role in modulation of the feeding response.

Why do inhibitory transmitters prolong the duration of the response to GSH and excitatory transmitters reduce it? A satisfactory answer to the question is hampered by the lack of detailed or sufficient information on basic facts such as cellular and regional receptor localization; neurochemical anatomy of the circuitry involved; identification, localization and timing of response of effectors to GSH and/or of the GSH signal transduction pathway; detailed analysis of the processes leading to mouth opening. Nonetheless, a provisional working hypothesis, based on the assumption that regulation of local excitation and inhibition in the hypostome by neurotransmitters and GSH may produce different results with respect to the body column (shown in Fig. 5), could help to focus on aspects and problems to be addressed in future experiments.

In conclusion, despite the incompleteness of the picture, a growing body of evidence supports the hypothesis that in Hydra the coordinated neural activation and inhibition of the contractile elements responsible for mouth closure in response to $\mathrm{GSH}$ stimulation is finely tuned by GABA and glutamate with opposite actions, while glycine has a dual role. The receptors subserving the amino acids actions appear to belong to the LGIC superfamily by their pharmacological properties, and may be prototypical molecules, with more than one functional role. The ability to perceive and react to chemical stimuli with appropriate responses is a primary tool for survival of multicellular organisms. Understanding development and evolution of the molecular machinery needed to integrate cell signaling and effector output can take advantage of a comparative approach. A better knowledge of the mechanisms regulating the feeding behavior in Hydra would be of interest for cnidarian physiologists, but could also add useful information for understanding the evolution of structure and functions of the basic tools of cellular signaling, the ligand-gated ion channel receptors.

\section{Acknowledgements}

I wish to thank Dr. G. Kass-Simon for many enlightening discussions and Dr. B. Galliot for helpful suggestions and critical reading of the manuscript. I am indebted with G. Stelo for skillful assistance in computer graphics. This work was partially supported by MIUR, grant FIRB 20012003, RBN01KJHT-007.

\section{References}

ALEXANDER, S.P.H., MATHIE, A., PETERS, J.A. (2007). Guide to Receptors and Channels (GRAC), 2nd edition (2007 Revision). Br J Pharmacol. 150: S1-S168.

ANCTIL, M. (2009). Chemical transmission in the sea anemone Nematostella vectensis: A genomic perspective. Comp Biochem Physiol Part D 4: 268-289.

ANCTIL, M., CARETTE, J-P. (1994). Glutamate immunoreactivity in non-neuronal cells of the sea anemone Metridium senile. Biol Bull 187: 48-54.

ANCTIL, M., MINH, C.N. (1997). Neuronal and nonneuronal taurine-like immunoreactivity in the sea pansy, Renilla koellikeri (Cnidaria, Anthozoa). Cell Tissue Res 288: 127-137.

ANDERSON, P.A.V. (1980). Epithelial conduction: its properties and functions. Prog Neurobiol 15: 161-203.

ANDERSON, P.A.V. (1985). Physiology of a bidirectional, excitatory chemical synapse. J Neurophysiol 53: 821-835.

ANDERSON, P.A.V. (2004). Cnidarian neurobiology: what does the future hold? Hydrobiologia 530/531: 107-116.

ANDERSON, P.A.V., GRUNERT, U. (1988). Three-dimensional structure of bidirectional, excitatory chemical synapses in the jellyfish Cyanea capillata. Synapse 2: 606-613.

ANDERSON, P.A.V., SPENCER, A.N. (1989). The importance of cnidarian synapses 
for neurobiology. J Neurobiol 20: 435-457.

ANDERSON, P.A.V., TRAPIDO-ROSENTHAL, H.G. (2009). Physiological and chemical analysis of neurotransmitter candidates at a fast excitatory synapse in the jellyfish Cyanea capillata (Cnidaria, Scyphozoa). Invert Neurosci 9: 167-173.

BARNARD, E. A., SKOLNIK, P., OLSEN, R. W., MOHLER, H., SIEGHART, W., BIGGIO, G., BRAESTRUP, C., BATESON, A. N, LANGER, S. Z. (1998). International Union

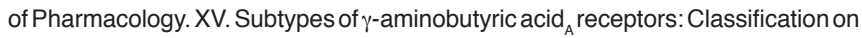
the bases of subunit structure and receptor function. Pharmacol Rev50:291-313.

BELLIS, S.L., GROSVENOR, W., KASS-SIMON, G., RHOADS, D.E. (1991). Chemoreception in Hydra vulgaris (attenuata): initial characterization of two distinct binding sites for L-glutamic acid. Biochim Biophys Acta 1061: 89-94.

BELLIS, S.L., KASS-SIMON, G., RHOADS, D.E. (1992). Partial characterization and detergent solubilization of the putative glutathione chemoreceptor from Hydra. Biochemistry 31: 9838-9843.

BETZ, H., KUHSE, J., SCHMIEDEN, V., LAUBE, B., KIRSCH, J., HARVEY, R.J. (1999). Structure and functions of inhibitory and excitatory glycine receptors. Ann NY Acad Sci 868: 667-676.

BODE, H.R., DAVID, C.N. (1978). Regulation of a multipotent stem cell, the interstitial cell of Hydra. Prog Biophys Mol Biol 33: 189-206.

BODE, H., DUNNE, J., HEIMFELD, S., HUANG, L., JAVOIS, L., KOIZUMI, O., WESTERFIELD, J., YAROSS, M. (1986). Transdifferentiation occurs continuously in adult Hydra. Curr Topics Dev Biol 20: 257-280.

BOHENING D., SNYDER, S.H. (2003). Novel neural modulators. Annu Rev Neurosci 26: 105-131.

BREJC, K., VANDIJK, W.J., KLAASSEN, R.V., SCHUURMANS, M., VANDEROOST, J., SMIT, A.B., SIXMA, T.K. (2001). Crystal structure of an ACh-binding protein reveals the ligand-binding domain of nicotinic receptors. Nature 411: 269-276.

BULLOCK, T.H., HORRIDGE, G.A. (1965). Structure and Function in the Nervous Systems of Invertebrates, Vol. 1, W.A. Freeman \& Co., San Francisco, pp 459-534.

CAMPBELL, R.D. (1987). Structure of the mouth of Hydra spp: A breach in the epithelium that disappears when it closes. Cell Tissue Res 249: 189-197.

CARLBERG, M.K., ALFREDSSON, K., MIELSEN, S-O., ANDERSON, P.A.V. (1995). Taurine-like immunoreactivity in the motor nerve net of the jellyfish Cyanea capillata. Biol Bull 188: 78-82.

CARLYLE, R.F. (1974). The occurrence in and action of amino acids on isolated supra oral sphincter preparations of the sea anemone Actinia equina. J Physiol (London) 236: 635-652.

CASTANO, P., ROSSI, S. (1978). Cytochemical ultrastructural and fluorescence study of the nervous net of Hydra sp. J Submicr Cytol 10: 381-395.

CHAPMAN, J.A., et al., (2010). The dynamic genome of Hydra. Nature 464: 592-596.

CHAUDHARI, N., LANDIN, A.M., ROPER, S D. (2000). A metabotropic receptor variant functions as a taste receptor. Nat Neurosci 3: 113-119.

CHEN, G.Q., CUI, C., MAYER, M.L., GOUAUX, E. (1999). Functional characterization of a potassium-selective prokaryotic glutamate receptor. Nature 402: 907-914.

COBB, M.H., HEAGY, W., DANNER, J., LENHOFF, H.M., MARSHALL, G.R. (1980). Effect of glutathione on cyclic nucleotide levels in Hydra attenuata. Comp Biochem Physiol 65C: 111-115.

COCKCROFT, V.B., OSGUTHORPE, D.J., BARNARD, E.A., FRIDAY, A.E., LUNT, G.G. (1990). Ligand-gated ion channels. Homology and diversity. Mol Neurobiol 4: 129-169.

COLASANTI, M., VENTURINI, G., MERANTE, A., MUSCI, G., LAURO, G.M. (1997). Nitric oxide involvement in Hydra vulgaris very primitive olfactory-like system. $J$ Neurosci 17: 493-499.

CONCAS, A., PIEROBON, P., MOSTALLINO, M.C., PORCU, P., MARINO, G., MINEI, R., BIGGIO, G. (1998). Modulation of $\gamma$-aminobutyric acid (GABA) receptors and the feeding response by neurosteroids in Hydra vulgaris. Neuroscience 85: 979-988.

CRISTINO, L., GUGLIELMOTTI, V., COTUGNO, A., MUSIO, C, SANTILLO, S. (2008). Nitric oxide signaling pathways at neural level in invertebrates: functional implications in cnidarians. Brain Res 1225: 17-25.

DAVIS, L.E., BURNETT, A.L., HAYNES, J.F. (1968). Histological and Ultrastructural Study of the Muscular and Nervous System in Hydra. II. Nervous System. J Exp Zool 167: 295-332.

DE LAAT, S.W., TERTOOLEN, L.G.J., GRIMMELIKHUIJZEN, C.J.P. (1980). No junctional communication between epithelial cells in hydra. Nature 288: 711-713.
DELGADO. L.M., COUVE, E, SCHMACHTENBERG, O. (2010). GABAand glutamate immunoreactivity in tentacles of the sea anemone Phymactis papillosa (LESSON 1830). J Morphol 271: 845-852.

DELLISANTI, C.H., YAO, Y., STROUD, J.C., WANG, Z.Z., CHEN, L. (2007). Crystal structure of the extracellular domain of nACh $\alpha 1$ bound to $\alpha$-bungarotoxin at 1.94 $A^{\circ}$ resolution. Nat Neurosci 10: 953-962.

DENKER, E., CHATONNET, A., RABET, N. (2008). Acetylcholinesterase activity in Clytia hemisphaerica (Cnidaria). Chem-Biol Interact 175: 125-128.

DENT, J.A. (2006). Evidence for a diverse Cys-loop ligand-gated ion channel superfamily in early bilateria. J. Mol Evol 62: 523-535.

DENT, J.A. (2010). The evolution of pentameric Ligand-Gated lon Channels. In Insect nicotinic acetylcholine receptors (Ed. S.H.Thany). Springer-Verlag, Berlin, pp 11-23.

DINGLEDINE, R., BORGES, K., BOWIE, D., TRAYNELIS, S.F. (1999). The glutamate receptor ion channels. Pharmacol Rev 51: 8-61.

DUNNE, J.F., JAVOIS, L.C., HUANG, L.W., BODE, H.R. (1985). A subset of cells in the nerve net of Hydra oligactis defined by a monoclonal antibody: Its arrangement and development. Dev Biol 109: 41-53.

DURRNAGEL, S., KUHN, A., TSIAIRIS, C.D., WILLIAMSON, M., KALBACHER, H., GRIMMELIKHUIJZEN, C.J.P., HOLSTEIN, T.W., GRUNDER. S. (2010). Three homologous subunits form a high-affinity peptide-gated ion channel in Hydra. $J$ Biol Chem 285: 11958-11965.

ECCLES, J.C. (1957). The physiology of nerve cells. Johns Hopkins Press, Baltimore \& Oxford University Press, London.

ERZEN, I., BRZIN, M. (1978). Cholinergic mechanisms in Hydra. Comp Biochem Physiol 59C: $39-43$.

EVANS, M.L., USHERWOOD, P.N.R. (1995). The effects of lectins on desensitization of locust muscle glutamate receptors. Brain Res 358: 34-39.

FALUGI, C., MORRI, C., BOUILLON, J., BOERO, F. (1994). Localization of some neurotransmitters during development in hydroidomedusae. Tissue \& Cell26:523-538.

FILSHIE, B.K., FLOWER, N.E. (1977). Junctional structures in Hydra. J Cell Sci 23: $151-172$.

FLOOR DISCUSSION (1961). Is there a nervous system in Hydra? In The biology of Hydra (Ed. H.M. Lenhoff \& W.F. Loomis) University of Miami Press, Coral Gables, Florida, pp 69-76.

FOORD, S.M., BONNER, T., NEUBIG, R.R., ROSSER, E.M., PIN, J.P., DAVENPORT, A.P., SPEDDING, M., HARMAR, A.J. (2005). International Union of Pharmacology. XLVI. G protein-coupled receptor list. Pharmacol Rev 57: 279-288.

FUJISAWA, T. and HAYAKAWA, E. (2012). Peptide signaling in Hydra. Int J Dev Biol 56: 543-550.

GALLIOT, B., QUIQUAND, M., GHILA. L., DE ROSA, R., MILJKOVIC-LICINA, M., CHERA, S. (2009). Origins of neurogenesis, a cnidarian view. Dev Biol332: 2-24.

GALLIOT, B., QUIQUAND, M. (2011). A two-step process in the emergence of neurogenesis. Eur J Neurosci 34: 847-862.

GALLIOT, B., SCHMID, V. (2002). Cnidarians as a model system for understanding evolution and regeneration. Int J Dev Biol 46: 39-48.

GIERER, A. (1977). Biological features and physical concepts of pattern formation exemplified by Hydra. Curr Topics Dev Biol 11: 17-59.

GIROSI, L., FERRANDO, S., BELTRAME, F., CIARCIA, G., DIASPRO, A., FATO, M., MAGNONE, M., RAITERI, L., RAMOINO, P., TAGLIAFIERRO, G. (2007). Gamma-aminobutyric acid and related molecules in the sea fan Eunicella cavolini (Cnidaria: Octocorallia): a biochemical and immunohistochemical approach. Cell Tissue Res 329: 187-196.

GITTER, A.H., OLIVER, D., THURM, U. (1994). Calcium- and voltage-dependence of nematocyst discharge in Hydra vulgaris. J Comp Physiol A 175: 115-122.

GOLUBOVIC, A., KUHN, A., WILLIAMSON, M., KALBACHER, H., HOLSTEIN, T.W., GRIMMELIKHUIJZEN, C.J.P., GRUNDER, S. (2007). A peptide-gated ion channel from the freshwater polyp Hydra. J Biol Chem 282: 35098-35103.

GOLZ, R., THURM, U. (1992). Monoclonal antibodies against surface components of the mechano- and chemosensitive cnidocil complex of Hydra vulgaris. Cell Tissue Res 268: 327-333.

GRIMMELIKHUIJZEN, C.J.P., LEVIEV, I., CARSTENSEN, K. (1996). Peptides in the nervous system of cnidarians: structure, function and biosynthesis. Int Rev Cytol 167: 37-89.

GRIMMELIKHUIJZEN, C.J.P., WILLIAMSON, M., HANSEN, G.N. (2002). Neuropep- 
tides in cnidarians. Can J Zool 80:1690-1702.

GROSVENOR, W., BELLIS, S.L., KASS-SIMON, G., RHOADS, D.E. (1992). Chemoreception in hydra: specific binding of glutathione to a membrane fraction. Biochim Biophys Acta 1117: 120-125.

GROSVENOR, W., RHOADS, D. E., KASS-SIMON, G. (1996). Chemoreceptive control of feeding processes in Hydra. Chem Senses 21: 313-321.

HODGKIN, A.L., HUXLEY, A.F. (1939). Action potentials recorded from inside a nerve fibre. Nature 144: 710-712.

HOLSTEIN, T.W., HOBMAYER, E., TECHNAU, U. (2003). Cnidarians: An evolutionarily conserved model system for regeneration? Dev Dyn 226: 257-267.

HOLTMAN, M., THURM, U. (2001). Mono- and oligo-vesicular synapses and their connectivity in a cnidarian sensory epithelium. J Comp Neurol 432: 537-549.

HORRIDGE, G.A., MACKAY, B. (1962). Naked axons and symmetrical synapses in coelenterates. Quart J Micro Sci 103: 531-541.

HUFNAGEL, L.A., KASS-SIMON, G. (1976). The ultrastructural basis for the electrical coordination between epithelia of Hydra. In Coelenterate Ecology and Behavior (Ed. G.O. Mackie). Plenum Press, New York, pp 695-704.

HUFNAGEL, L.A., KASS-SIMON, G. (1988). Functional anatomy of nematocyte innervation in battery cell complexes of the Hydra tentacle. In The Biology of Nematocysts (Eds. D.A. Hessinger, H.M. Lenhoff). Academic Press, New York, pp 519-531.

HUFNAGEL, L.A., KASS-SIMON, G., LYON, M.K. (1985). Functional organization of battery cell complexes in tentacles of Hydra attenuata. J Morph 184: 323-341.

JANÁKY, R., SHAW, C.A., VARGA, V., HERMANN, A., DOHOVICS, R., SARANSAARI, P., OJA, S.S. (2000). Specific glutathione binding sites in pig cerebral cortical synaptic membranes. Neuroscience 95: 617-624.

JHA, R.K., MACKIE, G.O. (1967). The recognition, distribution and ultrastructure of hydrozoan nerve elements. J Morphol 123: 43-61.

JOSEPHSON, R.K. (1974). Cnidarian neurobiology. In Coelenterate Biology. Reviews and new perspectives (Eds. L. Muscatine \& H.M. Lenhoff). Academic Press, New York, pp 245-280.

KASS-SIMON, G. (1972). Longitudinal conduction of contraction burst pulses from hypostomal excitation loci in Hydra attenuata. J Comp Physiol 80: 29-49.

KASS-SIMON, G. (1976). Coordination of juxtaposed muscle layers as seen in Hydra. In Coelenterate Ecology and Behavior (Ed. G.O. Mackie). Plenum Press, New York, pp 705-714.

KASS-SIMON, G., PANNACCIONE, A., PIEROBON, P. (2003). GABA and glutamate receptors are involved in modulating pacemaker activity in hydra. Comp Biochem Physiol Part A 136: 329-342.

KASS-SIMON, G., PASSANO, L.M. (1978). A neuropharmacological analysis of the pacemakers and conducting tissues of Hydra attenuata. J Comp Physiol A 128: $71-79$.

KASS-SIMON, G \& SCAPPATICCI, A.A. (2004). Glutamatergic and GABAnergic control in the tentacle effector systems of Hydra vulgaris. Hydrobiologia 530/531: 67-71.

KASS-SIMON, G., PIEROBON, P. (2007). Cnidarian chemical neurotransmission: an updated overview. Comp Biochem Physiol Part A 146: 9-25.

KATZ, B. (1971). Quantal mechanism of neural transmitter release. Science 173: 123-126.

KAY, J.C., KASS-SIMON, G. (2009). Glutamatergic transmission in Hydra: NMDA/Dserine affects the electrical activity of the body and tentacles of Hydra vulgaris. Biol Bull 216: 113-125.

KINNAMON, J.C., WESTFALL, J.A. (1981). A three-dimensional serial reconstruction of neuronal distributions in the hypostome of Hydra. J Morph 168: 321-329.

KLECKNER, N.W., DINGLEDINE, R. (1988). Requirement for glycine in activation of NMDA receptors expressed in Xenopus oocytes. Science 214: 835-837.

KOIZUMI, O. (2007). Nerve ring of the hypostome in Hydra: Is it an origin of the central nervous system of bilaterian animals? Brain Behav Evol 69: 151-159.

KOIZUMI, O., BODE, H.R. (1986). Plasticity in the nervous system of adult Hydra I. The position-dependent expression of FMRFamide-like immunoreactivity. Dev Biol 116: 407-421.

KOIZUMI, O., BODE, H.R. (1991). Plasticity in the nervous system of adult Hydra III. Conversion of neurons to expression of a vasopressin-like immunoreactivity depends on axial location. $J$ Neurosci 11: 2011-2020.

KOIZUMI, O., ITAZAWA, M., MIZUMOTO, H., MINOBE, J., JAVOIS, C., GRIMMELIKHUIJZEN, C.J.P., BODE, H.R. (1992). Nerve ring of the hypostome in Hydra.
I. Its structure, development and maintenance. J Comp Neurol 326: 7-21.

KOIZUMI, O., SATO, N., GOTO, C. (2004). Chemical anatomy of hydra nervous system using antibodies against hydra neuropeptides: a review. Hydrobiologia 530/531: 41-47.

LENHOFF, H.M. (1961). Activation of the feeding reflex in Hydra littoralis. I. Role played by reduced glutathione, and quantitative assay of the feeding reflex. $J$ Gen Physiol 45: 331-344.

LENHOFF, H.M. (1974). On the mechanism of action and evolution of receptors associated with feeding and digestion. In Coelenterate biology. Reviews and new perspectives (Eds. L. Muscatine \& H.M. Lenhoff). Academic Press, New York, pp 211-243.

LENHOFF, H.M. (1977). Aquatic Invertebrates: Model systems for study of receptor activation and evolution of receptor proteins. Ann Rev Pharmacol Toxicol 17: 243-258.

LENTZ, T.L. (1966). The cell biology of hydra. North-Holland Publ. Co., Amsterdam, pp 11-12, 124-142.

LENTZ, T.L. (1968). Primitive nervous systems. Yale University Press, New Haven.

LENTZ, T.L., BARRNETT, R.J. (1961). Enzyme histochemistry of hydra. J Exp Zool 147: $125-149$.

LENTZ, T.L., BARNETT, R.J. (1962). The effect of enzyme substrates and pharmacological agents on nematocyst discharge. J Exp Zool 149: 33-38.

LENTZ, T.L., BARNETT, R.J. (1963). The role of the nervous system in regenerating hydra. The effect of neuropharmocological agents. J Exp Zool 154: 305-327.

LOEWI, O. (1921). Uber humorole Ubertragbarkeit der Herznervenwirkung. I. Mitteilung. Pluger's Arch 189: 239-242.

LOOMIS, W.F. (1955). Glutathione control of the specific feeding reactions of Hydra. Ann NY Acad Sci 62: 211-227.

LYNCH, J.W. (2004). Molecular structure and function of the glycine receptor chloride channel. Physiol Rev 84: 1061-1095.

MACKIE, G.O. (1990). The elementary nervous system revisited. Am Zoo/30: 907-920.

MACKIE, G.O. (1989a). Evolution of cnidarian giant axons. In Evolution of the First Nervous Systems (Ed. P.A.V. Anderson). Plenum Press, New York, pp 395-407.

MACKIE G.O. (1989b). Louis Agassiz and the discovery of the coelenterate nervous system. Hist Philos Life Sci 11: 71-81.

MACKIE, G.O., PASSANO, L.M. (1968). Epithelial conduction in hydromedusae. J Gen Physiol 52: 600-621.

MACKLIN, M, JOSEPHSON, R.K. (1971). The ionic requirements of transepithelial potentials in Hydra. Biol Bull 141: 299-318.

MARLOW, H.Q., SRIVASTAVA, M., MATUS, D.Q., ROKHSAR, D., MARTINDALE, M.Q. (2009). Anatomy and development of the nervous system of Nematostella vectensis, an anthozoan cnidarian. Dev Neurobiol 69: 235-254.

MARTIN, V.J. (2004). Photoreceptors of cubozoan jellyfish. Hydrobiologia530/531:135144.

MARTIN, S.M., SPENCER, A.N. (1983). Neurotransmitters in coelenterates. Comp Biochem Physiol 74 C: 1-14.

MARTINEZ, D., BRIDGE, D. (2012). Hydra, the everlasting embryo, confronts aging. Int J Dev Biol 56: 479-487.

MAYER M.L., ARMSTRONG N. (2004). Structure and function of glutamate receptor ion channels. Annu Rev Physiol 66: 161-81.

MENDES, E.G., FREITAS, J.C. (1984). The responses of isolated preparations of Bunodosoma caissarum (Cora, 1964) (Cnidaria, Anthozoa) to drugs. Comp Biochem Physiol 79 C: 375-382.

MOTHET, J.P., PARENT, A.T., WOLOSKER, H., BRADY, R.O., LINDEN, D.J., FERRIS, C.D., ROGAWSKI, M.A., SNYDER, S.H. (2000). D-Serine is an endogenous ligand for the glycine site of the N-methyl-D-aspartate receptor. Proc Natl Acad SCi USA 97: 4926-4931.

NAKANISHI, N., HARTENSTEIN, V., JACOBS. D.K. (2009). Development of the rhopalial nervous system in Aurelia sp. 1 (Cnidaria, Scyphozoa). Dev Genes Evol 219: 301-317.

OGITA, K., ENOMOTO, R., NAKAHARA, F., ISHITSUBO, N., YONEDA, Y. (1995). A possible role of glutathione as an endogenous agonist at the $\mathrm{N}$-methyl-D-aspartate recognition domain in rat brain. $J$ Neurochem 64: 1088-1096.

OHTA, K., HANAI, K., MORITA, H. (1992). Glutathione-binding proteins identified by monoclonal antibodies which depress the behavioral response evoked by glutathione in Hydra. Biochim Biophys Acta 1117: 136-142. 
OLIVER, D., BRINKMANN, M., SIEGER, T., THURM, U. (2008). Hydrozoan nematocytes send and receive synaptic signals induced by mechano-chemical stimuli. $J$ Exp Biol 211: 2876-2888.

OLSEN, R. W., SIEGHART, W. (2008). International Union of Pharmacology. LXX.

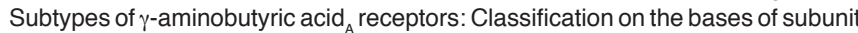
structure and receptor function. Update. Pharmacol Rev 60:243-260.

ORTELLS, M.O., LUNT, G.G. (1995). Evolutionary history of the ligand-gated ion channel superfamily of receptors. Trends Neurosci 18: 121-127.

OTSUKA, M., IVERSEN, L.L., HALL, Z.W., KRAVITZ, E.A. (1966). Release of gamma-aminobutyric acid from inhibitory nerves of lobster. Proc Natl Acad $\mathrm{Sci}$ USA. 56: 1110-1115.

PANTIN, C.F. (1952). The elementary nervous system. Proc $R$ Soc Lond B Biol Sci 140: $147-168$.

PARKER, G. H. (1919). The elementary nervous system. Lippincott, Philadelphia.

PASSANO, L.M. (1963). Primitive nervous systems. Proc Natl Acad Sci USA 50: 306-313.

PASSANO, L.M., McCULLOUGH, C.B. (1964). Co-ordinating systems and behaviour in Hydra I. Pacemaker system of the periodic contraction. J Exp Biol 41: 643-664.

PASSANO, L.M., McCULLOUGH, C.B. (1965). Co-ordinating systems and behaviour in Hydra II. The rhythmic potential system. J Exp Biol 42: 205-231.

PIEROBON, P., CONCAS, A., SANTORO, G., MARINO, G., MINEI, R., PANNACCIONE, A., MOSTALLINO, M.C., BIGGIO, G. (1995). Biochemical and functional identification of GABA receptors in Hydra vulgaris. Life Sci 56: 1485-1497.

PIEROBON, P., MINEI, R., PORCU, P., SOGLIANO, C., TINO, A., MARINO, G., BIGGIO, G., CONCAS, A. (2001). Putative glycine receptors in Hydra: a biochemical and behavioral study. Eur J Neurosci 14: 1659-1666.

PIEROBON, P., SOGLIANO, C., MINEI, R., TINO, A., PORCU, P., MARINO, G., TORTIGLIONE, C., CONCAS, A. (2004a). Putative NMDA receptors in Hydra: a biochemical and functional study. Eur J Neurosci 20: 2598-2604.

PIEROBON, P., TINO, A., MINEI, R., MARINO, G. (2004b). Different roles of GABA and glycine in modulation of chemosensory responses in Hydra vulgaris (Cnidaria, Hydrozoa). Hydrobiologia 530/531: 59-66.

PUTNAM, N.H. et al., (2007). Sea anemone genome reveals ancestral eumetazoan gene repertoire and genomic organization. Science 317: 86-94.

RAJENDRA, S., LYNCH, J.W., PIERCE, K.D., FRENCH, C.R., BARRY, P.H., SCHOFIELD, P.R. (1995). Mutation of an arginine residue in the human glycine receptor transforms $\beta$-alanine and taurine from agonists into competitive antagonists. Neuron 14: 169-175.

ROMANES, G.J. (1885). Jelly-fish, star-fish, and sea urchins, being a research on primitive nervous systems. D. Appleton \& Co., New York.

RUGGIERI, R. D., PIEROBON, P., KASS-SIMON, G. (2004). Pacemaker activity in hydra is modulated by glycine receptor ligands. Comp Biochem Physiol Part A 138: 193-202.

RUSHFORTH, N.B. (1971). Behavioral and electrophysiological studies of Hydra. I. Analysis of contraction pulse patterns. Biol Bull 140: 255-273.

RUSHFORTH, N.B., BURKE, D.S. (1971). Behavioral and electrophysiological studies of Hydra. II. Pacemaker activity of isolated tentacles. Biol Bull 140: 502-519.

RUSHFORTH, N.B., HOFMAN, F. (1972). Behavioral and electrophysiological studies of Hydra. III. Components of feeding behavior. Biol Bull 142: 110-131.

SALLEO, A., MUSCI, G., BARRA, P.F.A., CALABRESE, L. (1996). The discharge mechanism of acontial nemocytes involves the release of nitric oxide. J Exp Biol 199: 1261-1267.

SATTERLIE, R.A. (2002). Neuronal control of swimming in jellyfish: a comparative story. Can J Zool 80: 1654-69.

SATTERLIE, R.A., SPENCER, A.N. (1987). Organization of conducting systems in 'simple' invertebrates: Porifera, Cnidaria and Ctenophora. In Nervous systems in Invertebrates (Ed. M.A. Ali). Plenum Press, New York, pp 213-264.

SCAPPATICCI,A.A., JACQUES, R., CARROLL, J.E., HUFNAGEL, L.A., KASS-SIMON, G. (2004). Immunocytochemical evidence for an NMDA1 receptor subunit in dissociated cells of Hydra vulgaris. Cell Tissue Res 316: 263-270.

SCAPPATICCI, A.A., KASS-SIMON, G. (2008). NMDA and GABA B $_{B}$ receptors are involved in controlling nematocyst discharge in hydra. Comp Biochem Physiol Part A 150: 415-422.

SCEMES, E. (1989). Rethinking the role of cholinergic neurotransmitters in the Cnidaria. In Evolution of the First Nervous Systems (Ed. P.A.V. Anderson). Plenum
Press, New York, pp 157-166.

SHAW, C. A. (1998). Glutathione in the nervous system. Taylor \& Francis, Bristol.

SHELTON, G.A.B. (1982). Electrical conduction and behaviour in 'simple'invertebrates. Clarendon Press, Oxford, pp 73-148.

SPENCER, A.N. (1974). Non-nervous conduction in invertebrates and embryos. Am Zool 14: 917-929.

SPENCER, A.N. (1989). Chemical and electrical synaptic transmission in the Cnidaria. In Evolution of the First Nervous Systems (Ed. P.A.V. Anderson). Plenum Press, New York, pp 33-53.

TAKAHASHI, T., HAMAUE, N. (2010). Molecular characterization of Hydra acetylcholinesterase and its catalytic activity. FEBS Lett 584: 511-516.

TALESA, V, PRINCIPATO, G. B., MANGIABENE, C., GIOVANNINI, E., NORTON, S. J., ROSI, G. (1992). Cholinesterase in the Cnidarians Velella velella (Hydrozoa: Syphonophora) and Actinia equina (Anthozoa: Actiniaria): a comparative study. J Exp Zool 263: 367-373.

TARDENT, P. (1963). Regeneration in the Hydrozoa. Biol Rev 38: 293-333.

TASNEEM, A., IYER, L. M., JAKOBSSON, E., ARAVIND, L. (2004). Identification of the prokaryotic ligand-gated ion channels and their implications for the mechanisms and origins of animal Cys-loop ion channels. Genome Biol 6: R4.

TECHNAU, U., HOLSTEIN, T.W. (1995). Boundary cells of endodermal origin define the mouth of Hydra vulgaris (Cnidaria). Cell Tissue Res 280: 235-242.

THURM, U., BRINKMANN, M., GOLZ, R., HOLTMANN, M., OLIVER, D., SIEGER, T. (2004). Mechanoreception and synaptic transmission of hydrozoan nematocytes. Hydrobiologia 530/531: 97-105.

TIKHONOV, D.B., MAGAZANIK, L.G. (2009). Origin and molecular evolution of ionotropic glutamate receptors. Neurosci Behav Physio/ 39: 763-773.

TREMBLEY, A. (1744). Memoires pour servir à l'histoire d'un genre de polypes d'eau douce á bras en forme de cornes. Jean \& Herman Verbeek, Leiden.

TSANG, S-Y., NG, S-K., XE, Z., XUE, H. (2006). The evolution of GABA A $_{\text {receptor-like }}$ genes. Mol Biol Evol 24: 1-12.

VAN MARLE, J. (1989). Catecholamines, related compounds and the nervous system in the tentacles of some anthozoans. In Evolution of the First Nervous Systems (Ed. P.A.V. Anderson). Plenum Press, New York, pp 129-140.

VENTURINI, G. (1987). The Hydra GSH receptor. Pharmacological and radioligand binding studies. Comp Biochem Physiol 87C: 321-324.

VENTURINI, G., CAROLEI, A. (1992). Dopaminergic receptors in Hydra. Pharmacological and biochemical observations. Comp Biochem Physiol 102C: 39-43.

WESTFALL, J.A. (1970). Ultrastructure of synapses in a primitive coelenterate. J Ultrastruct Res 32: 237-246.

WESTFALL, J.A. (1973a). Ultrastructural evidence for neuromuscular systems in coelenterates. Am Zool 13: 237-246.

WESTFALL, J.A. (1973b). Ultrastructural evidence for a granule-containing sensorymotor-interneuron in Hydra littoralis. J Ultrastruct Res 42: 268-282.

WESTFALL, J.A. (1987). Ultrastructure of invertebrate synapses. In Nervous systems in Invertebrates (Ed. M.A. Ali). Plenum Press, New York, pp 3-28.

WESTFALL, J.A. (1996). Ultrastructure of synapses in the first-evolved nervous systems. J Neurocytol 25: 735-746.

WESTFALL, J.A. (1988). Presumed neuronematocyte synapses and possible pathways controlling discharge of a battery of nematocysts in Hydra. In The biology of nematocysts (Eds. D.A. Hessinger \& H.M. Lenhoff). Academic Press, New York, pp 41-51.

WESTFALL, J.A., ELLIOTT, S.R., CARLIN, R.W. (2002). Ultrastructural evidence for two-cell and three-cell neural pathways in the tentacle epidermis of the sea anemone Aiptasia pallida. J Morph 251: 83-92.

WESTFALL, J.A., KINNAMON, J.C. (1978). A second sensory-motor-interneuron with secretory granules in Hydra. J Neurocytol 7: 365-379.

WESTFALL, J.A., KINNAMON, J.C. (1984). Perioral synaptic connections and their possible role in the feeding behavior of Hydra. Tissue \& Cell 16: 355-365.

WESTFALL, J.A., YAMATAKA, S., ENOS, P.D. (1971). Ultrastructural evidence of polarized synapses in the nerve net of Hydra. J Cell Biol 51: 318-323.

WOOD, J.G. (1979). The Fine Structure of the Hypostome and Mouth of Hydra II. Transmission Electron Microscopy. Cell Tissue Res 199: 319-338.

XUE, H. (1998). Identification of major phylogenetic branches of inhibitory ligand-gated channel receptors. J Mol Evol 47: 323-333. 


\section{Further Related Reading, published previously in the Int. J. Dev. Biol.}

Serotonin involvement in the metamorphosis of the hydroid Eudendrium racemosum Giuliana Zega, Roberta Pennati, Arianna Fanzago and Fiorenza De Bernardi

Int. J. Dev. Biol. (2007) 51: 307-313

NMDA-receptor blockade enhances cell apoptosis in the developing retina of the postnatal rat Maria Hernandez, Inmaculada Guerrikagoitia, Luis Martinez-Millan and Elena Vecino Int. J. Dev. Biol. (2007) 51: 117-122

The origin and evolution of the nervous system

Alain Ghysen

Int. J. Dev. Biol. (2003) 47: 555-562

The role of alpha-amidated neuropeptides in hydroid development--LWamides and metamorphosis in Hydractinia echinata

Günter Plickert, Eva Schetter, Nicole Verhey-Van-Wijk, Jörg Schlossherr, Marlis Steinbüchel and Martin Gajewski

Int. J. Dev. Biol. (2003) 47: 439-450

\section{Ca2+-ions and pattern control in Hydra}

Stefanie Zeretzke, Fernando Pérez, Kirsten Velden and Stefan Berking

Int. J. Dev. Biol. (2002) 46: 705-710

5 yr ISI Impact Factor $(2010)=2.961$

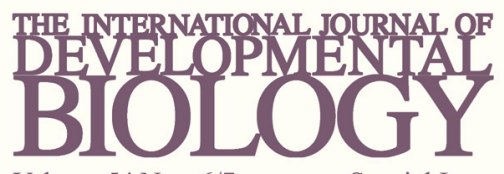

Volume 54 Nos. $6 / 7$
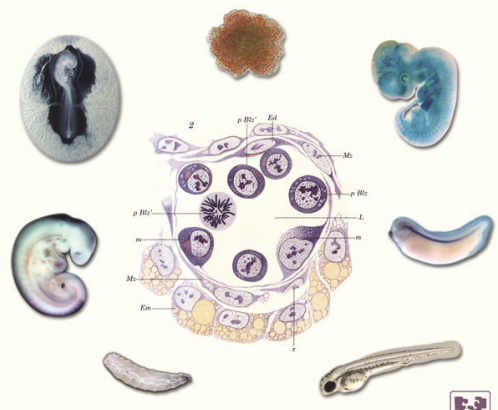

Developmental Hematopoiesis

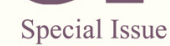

国

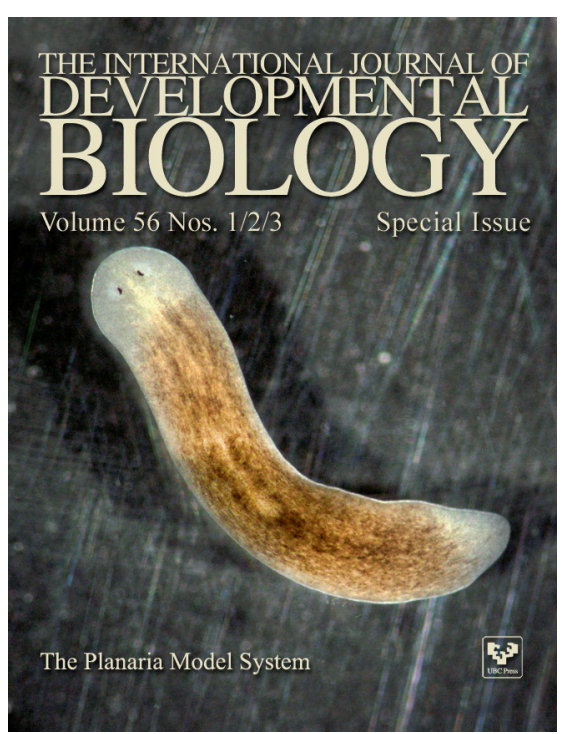

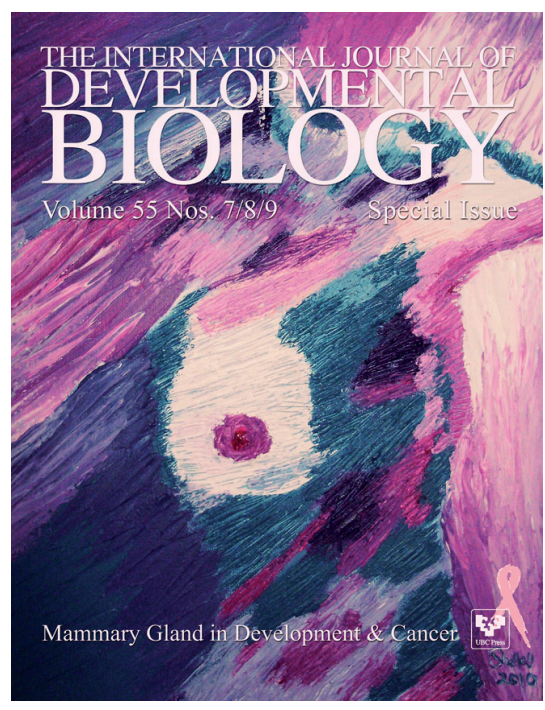
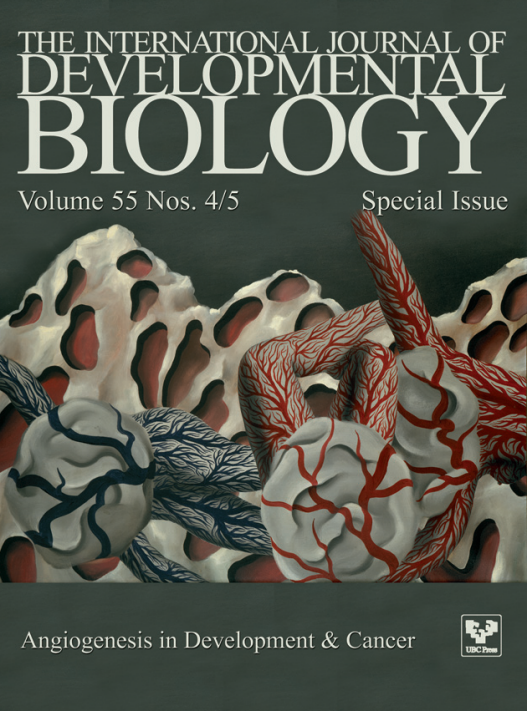